\title{
ORIGIN, MINERALOGY, AND CHEMISTRY OF MANGANIFEROUS AND FERRUGINOUS PRECIPITATES FOUND IN SAND AND GRAVEL DEPOSITS IN FINLAND
}

\author{
TAPIO KOLJONEN, PERTTI LAHERMO, and LIISA CARLSON
}

\begin{abstract}
KOLJONEN TAPIO, LAHERMO PERTTI, and CARLSON LIISA 1976: Bull. Geol. Soc. Finland 48: 111-135.

Different types of manganiferous and ferruginous precipitates found in glaciofluvial sediments are described. $\mathrm{Mn}$ is enriched into places where oxidizing conditions prevail, probably through chemical processes alone. In moist oxidates the enrichment of Mn originally coprecipitated with $\mathrm{Fe}$ continues through the partial dissolution of the precipitated $\mathrm{Mn}$-compounds in interparticle fluids. The only Mn-rich mineral identified through $\mathrm{X}$-ray diffraction of manganiferous cements was birnessite. It precipitates from groundwater instead of pure manganese oxides because of the foreign cations present. Of these, $\mathrm{Ca}$ seems to be the most important, while the amount of other cations: $\mathrm{Fe}, \mathrm{Al}, \mathrm{Mg}, \mathrm{K}$, and $\mathrm{Na}$, varies, and is dependent on the composition of percolating waters and the state of crystallization. Goethite and lepidocrocite were observed in ferruginous precipitates. Upon heating, birnessite recrystallizes as hausmannite and spinel when few foreign ions are present, and also as bixbyite if the sample contains enough iron. Ferruginous precipitates recrystallize as hematite upon heating. The precipitation of Mn-rich compounds from groundwater in which more $\mathrm{Fe}$ than $\mathrm{Mn}$ is present is tentatively attributed to the lower stability of $\mathrm{Mn}$-complexes - with organic and $-\mathrm{HCO}_{3}-$ ligands usually - which within higher $\mathrm{pH}-\mathrm{Eh}$ decompose in sand and gravel before Fe-complexes do. This leads, under suitable conditions, to the oxidation of $\mathrm{Mn}^{2+}$ in groundwater discharges and in well-aerated sediments. Fe precipitates after Mn because it is complex-bound and does not precipitate before the complex is destroyed, e.g., by organisms.
\end{abstract}

Tapio Koljonen and Liisa Carlson, Department of Geology and Mineralogy, University of Helsinki, P.O. Box 115, SF-00171 Helsinki 17, Finland.

Pertti Lahermo, Geological Survey of Finland, SF-02150 Espoo 15, Finland.

\section{Introduction}

The general principles of the separation of iron and manganese in exogenic processes have been discussed by Krauskopf (1957) and
Hem (1963, 1964); recently they have been discussed by Koljonen and Carlson (1975) and Vasari et al. (1972) in the context of Finland.

In Finland, $\mathrm{Fe}$ and $\mathrm{Mn}$ in oxidized form are 

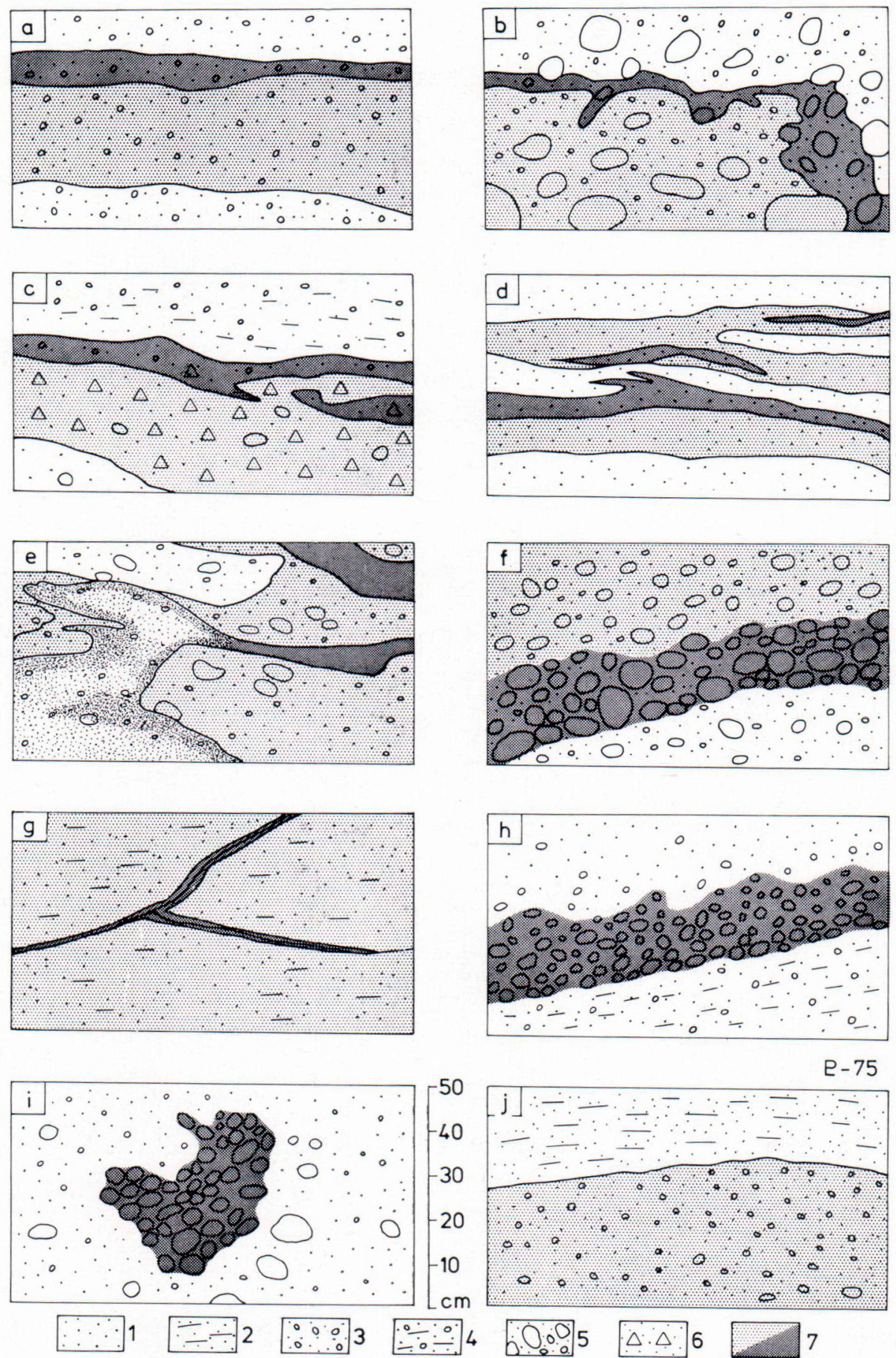

Fig. 1. The most common types of manganiferous and ferruginous precipitates found in sorted sediments in Finland. The type, probable origin, and occurrence are set out in Table 1. The drawings are simplified sketches taken from color photographs (cf. Figs. 4-6). Symbols: 1. Sand; 2 . Stratified sand; 3. Sand and gravel; 4. Stratified sand and gravel; 5. Gravel and pebbles; 6. Till or till-like poorly sorted material; 7. Fe-precipitate (light) and Mn-precipitate (dark). 
commonly precipitated as: lake and bog ore (cf. Halbach 1976; Koljonen and Carlson 1975); Fe-rich B horizon in podzolic soils (cf. Aaltonen 1941; Jauhiainen 1969, $1973 \mathrm{a}, \mathrm{b})$; Mn-rich podzols in the Arctic Regions of Norway and Finland (under study); pigment on mineral grains in sorted, especially glaciofluvial sediments (this paper); spotted precipitate in gleyed soils, and concretions in humus-rich silty clay (cf. Alhonen et al. 1975).

\section{Occurrence of manganiferous and ferrugi- nous precipitates in sand and gravel deposits}

Iron and manganese precipitates are found in sand and gravel, and are frequently uncovered when the material of eskers, deltas, and sandurs is utilized. Fe-rich precipitates are much more common than Mn-rich throughout Finland.

The most common types of precipitates are set out in Fig. 1 and Table 1. The Mn-rich types $a, b, f, h$, and $j$ are found in the esker studied and the others occur elsewhere.

\section{A case history of precipitates in an esker at the rural commune of Heinola}

\section{Description of the site}

Numerous Mn-Fe-rich precipitates are found on the walls of gravel pits between the ponds Vähä Samjärvi and Kokkalammi, a few kilometers $\mathrm{N}$ of the town of Heinola (Fig. 2). The gravel pits are situated in a radial esker sequence extending southward from Lusi, a village about $10 \mathrm{~km} \mathrm{~N}$ of Heinola, to the Second Salpausselkä, a great ice-marginal formation formed about 10300 years ago. Sometimes several parallel fragmentary esker ridges occur in the trenches of the bedrock. Ponds and small bogs fill some of the depressions which formed when the blocks of ice buried in sediments melted, causing the sediments to collapse. Consequently, the morphology of the esker is irregular and discontinuous.

The esker studied here is composed mostly of glaciofluvial sand and sandy gravel with stony intercalations. As the esker material has been utilized, numerous manganiferous and ferruginous precipitates have been exposed on the walls of the pits.

The surficial deposits of the investigated site have been mapped in detail and the positions of the upper limits of horizontal or gently dipping precipitate horizons have been levelled and plotted in profiles (Figs. 2 and 3 ). The evaluated original contour of the esker and the location of the groundwater table before exploitation are also set out in the profiles. The gradient of the groundwater table between Vähä Samjärvi and Kokkalammi is about $2.4 \%(13 \mathrm{~m}$ in $540 \mathrm{~m})$. Between points $300 \mathrm{~m}$ and $360 \mathrm{~m}$ it descends steeply, and discharges issue from many places (cf. Fig. 6). At the end of August 1974 the discharge of groundwater from the bottom of the pits was from 6 to 9 liters per second near the point $350 \mathrm{~m}$ (Fig. 3, longsection $\mathrm{A}-\mathrm{B}$ ).

The level of the groundwater table prevailing before the removal of gravel and sand has been estimated in Fig. 3. Especially between $210-320 \mathrm{~m}$, most of the precipitate stripes are situated near this former groundwater table. Late in the autumn of 1974 , the water flow was dammed by earth near the point $330 \mathrm{~m}$ (see also Fig. 2). An artificial pond was formed and the water level rose several meters to the height at which oxidate precipitates are found.

The bedrock to the north is composed of granite, granodiorite, and gneiss (Lehijärvi 1970). Because the movement of the continental ice sheet was from NW-N, silicic rocks with little $\mathrm{Fe}$ and $\mathrm{Mn}$ have the greatest 
influence on the lithology of the ridge material and the composition of the groundwater. Small occurrences of gabbroic and dioritic rocks to the south have no effect.

Podzolic soils prevail in the region, and near Vähä Samjärvi there lie small peat bogs at about groundwater level. These increase the content of low-polymerized organic acids in the soil and promote the disintegration of $\mathrm{Fe}-\mathrm{Mn}$-rich femic minerals. Groundwater in the soil is reducing before the acids are neutralized (cf. Table 3).

Table 1. Type, probable origin, and occurrence of manganiferous and ferruginous precipitates set out in Fig. 1.

a Uniform Mn-rich precipitate as regular horizontal layer above Fe-rich precipitate in homogeneous gravelly sand (cf. Fig. 4).

b Mn-rich precipitate as somewhat irregular layer above $\mathrm{Fe}$-rich precipitate in heterogeneous stomy and gravelly sand.

c Mn-rich precipitate as somewhat irregular layer above $\mathrm{Fe}$-rich precipitate along the contact of gravelly sand and underlying till-like material.

d Nearly horizontal Mnand Fe-rich precipitates as discontinuous layers at various depths in homogeneous sand.
Groundwater containing ferroiron reaches an area in esker where material of uniform permeability is well ventilated and aerated. Fe- and Mn-precipitates are formed along the groundwater table and somewhat above it.

In some places groundwater flow is turbulent because of coarse material. Mn-rich precipitates are formed in the bestaerated spots along small, fast flowing underground streams. This type of precipitate has a similar origin to type a.

Groundwater or perched water flows mainly along the contact between an upper bed and a lower one of smaller permeability. Mn-precipitates are formed along the contact, principally into the upper coarser gravelly material, which is better aerated.

In some occurrences the layering probably represents ancient paths of flowing vadose or perched water from which oxidates have been precipitated. In some cases this type of layering may be caused by slowly descending groundwater table.
This type of regular Mn-rich horizon overlying an Fe-rich one is often met on the walls of gravel pits in eskers, deltas, and sandurs and is seen after the descending of the groundwater table as a result of utilization of material. Usually the belt of $\mathrm{Mn}$-precipitates is only a few centimeters thick and $10-20 \mathrm{~m}$ long, but in one case it was c. $1 \mathrm{~m}$ thick. The layer of Fe-precipitates is usually much thicker than the overlying manganiferous one.

This type of somewhat irregular $\mathrm{Mn}-\mathrm{Fe}$-precipitate sequence is common. The horizontal magnitude of the belt is usually smaller than that of type a.

Uncommon. Form varies and the horizontal magnitude is usually small. In till, ferrugineous and manganiferous precipitates are generally not so common and well developed as in more pervious sand because conditions are more reducing in the former.

Most common type. Mn-precipitates are usually small and may be absent altogether. Ferich rusty layering may be present as pigment or cement on mineral grains throughout the deposit. Between precipitates there may be quite clear spots, usually consisting of finer material. 
e Irregular $\mathrm{Mn}$ - and $\mathrm{Fe}-$ precipitates in sandy gravel in which grain size greatly varies. Mn is concentrated in outer parts of Mn-rich spots.

f Mn-rich precipitates in the sheet of stony gravel under an Fe-rich layer of finer material (cf. Fig. $5)$.

g Mn-precipitate concentrated in fissures of sand hardened by Fe-rich cement.

h Mn-precipitates in a sheet of stony gravel surrounded by finer material with no traces of $\mathrm{Fe}$ rich precipitate.

i Mn-rich precipitates concentrated into blind clusters or veins of coarse material in finer sandy material (cf. types $f$ and h). There may be similar Fe-rich precipitates.
In flowing groundwater and perched water Mn tends to precipitate to more aerated parts where water flows fast. Therefore in nonhomogeneous coarse material where the flow in places is rather fast, and in some cases turbulent, Mn may precipitate in Fe-rich parts but mostly into the outer areas of the deposits (cf. type b).

$\mathrm{Mn}$ is precipitated from flowing groundwater or perched water seeping downwards into stony gravel intercalations under the finer, less aerated material into which $\mathrm{Fe}$ is enriched (cf. types $\mathrm{b}$ and e).

Probably Mn migrates in reduced form in soil and separates from iron into cracks because they are more aerated and may dry seasonally. A similar phenomenon has been observed in Mn-ores where cryptomelane crystallizes in syneresis cracks (Ostwald 1975). There is a tendency toward separation of $\mathrm{Fe}$ and $\mathrm{Mn}$ in moist oxidate deposits.

In glaciofluvial sediments, in which coarse and fine layers alternate, Mn tends to concentrate in the coarse material during deposition and may afterwards migrate to other sites in sediment (cf. types $\mathrm{c}$, e, and f). Some of the Mn-rich types (e.g. f and i) may also be fossil precipitates which have formed on stones just above the water level of lakes, rivers, and brooks, and they may be used as indicators of earlier shore lines (cf. also Shepps and Fairbridge 1968).

Like type $h$.
Occurrence and size like type b, but more rare.

Fairly common. Mn-rich parts may be some twenty or thirty centimeters thick and several meters wide. In general Mnprecipitates concentrate into coarser parts of deposits. Sometimes pure Mn-precipitate occurs abundantly as a needlelike mass.

Uncommon.

Fairly common (cf. type f).

Fe-rich precipitates of this type are very common and $\mathrm{Mn}$-rich fairly common. Both types are small in size. 


\section{Type}

j Fe-rich precipitate on coarse sand underlying fine sand.

Origin

Iron has been oxidized, and has precipitated from groundwater and perched water onto mineral grains as cement, especially in the phase of descending groundwater table.
Distribution and magnitude

Most common of all. Rusty pigment may be present over wide areas of deposits above the groundwater table.

\section{Oxidate precipitates}

The samples represent the different types of precipitates found in the esker. Their chemical composition is set out in Table 2, and that of ground- and surface-water samples in Tables 3 and 4 . The samples are described in the tables. Mineral compositions as studied by X-ray diffraction are set out in Figs. 7-10.

The manganiferous material in samples 1 , 2, $3 \mathrm{a}$, and $4 \mathrm{a}$ is nearly black in color and is a pepper-like precipitate more or less loosely fixed on mineral grains. The layer is thickest in the depressions on grain surfaces and is usually much thinner at the edges. The ferruginous material in $3 \mathrm{~b}$ and $4 \mathrm{~b}$ is from brown (grains) to yellow-brown (powder) and of varying grain size. In both samples it appears as a loose layer or pigment on sand grains.

The volume of $\mathrm{Mn}$ and Fe precipitates is usually dependent only on the chemical composition of groundwater and lithological composition of esker material. When these elements are able to migrate in groundwater and are present in sufficient quantity for precipitates to form the most decisive factors are $\mathrm{pH}$-Eh-conditions. When organisms are present only to a limited extent, the increase in $\mathrm{pH}-\mathrm{Eh}$ alone determines the oxidation and precipitation.

Manganiferous precipitates are usually much harder than ferruginous ones. They harden sand and gravel into dark boulders slid into the bottom of the pits or as outstanding edges on the walls of pits or on rocks.

In numerous places, aged precipitates can be found more than $10 \mathrm{~m}$ above the recent groundwater level, in some cases much higher than ancient groundwater levels (Fig. 3). The precipitates located near the recent groundwater level are young, having been formed during a period of several years when the water level in the esker has lowered as a result of excavations. The precipitates do not persist for prolonged periods in waterlogged sediment unless oxygen-rich percolating water is present.

Precipitates form in places where water flows fast or up to which groundwater seasonally ascends. In till and fine sand of low permeability there is more $\mathrm{Fe}$ than $\mathrm{Mn}$, but Mn content increases in coarse sorted sediments where aeration is better. $\mathrm{Fe}$ is frequently found over large areas of eskers as dispersed pigment on mineral grains, whereas $\mathrm{Mn}$, which is found much more rarely, is precipitated onto coarse material where water 


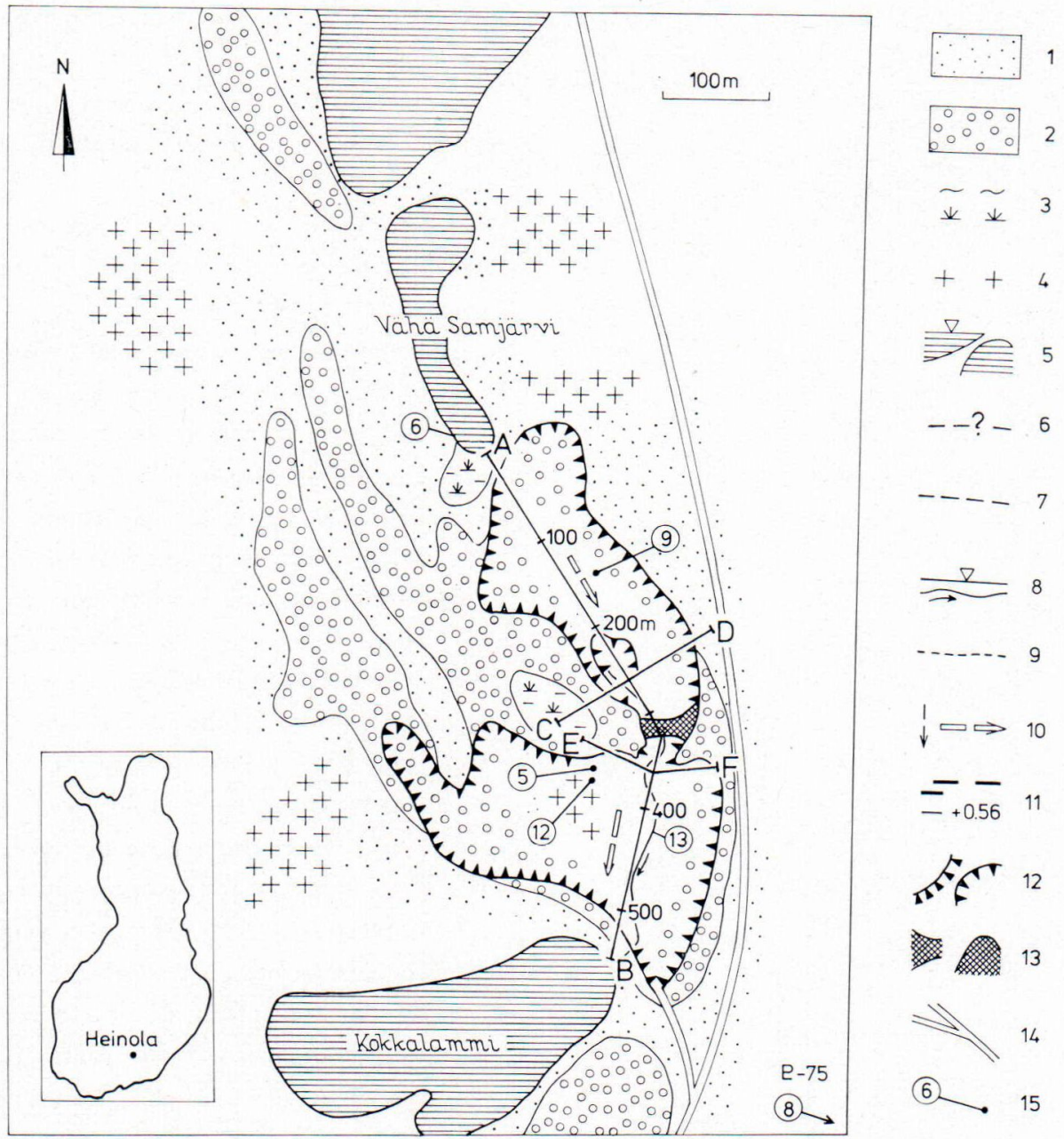

Fig. 2. An esker sequence containing oxidate prexipitates on the walls of gravel pits in the rural commune of Heinola. Symbols (refers also to Fig. 3): 1. Sand; 2. Sand and gravel; 3. Peat; 4 . Bedrock outcrop; 5. Surface water body; 6. Estimated earlier ground level of the esker before utilization of gravel; 7. Recent ground water table; 8. Recent outcropping groundwater table or groundwater discharge (spring) on the bottom of the pit and the ritulet originating from it; 9. Estimated earlier groundwater table; 10. Direction of ground water flow and vertical percolation; 11. Location of ferruginous or/and manganiferous precipitate (in meters in relation to the water level of the pond Vähä Samjärvi); 12. Gravel pit; 13. Earth dam built after investigations were begun; 14. Road; 15. Site of water sample.

flow is abundant, and migrates to restricted areas as precipitate with transitional or sharp contacts (cf. Figs. 4 and 5).

Mn-rich precipitates are black or bluishblack in color and, therefore, can be separated visually from the reddish or yellowish- brown Fe-rich ones. Precipitates are generally mixed but, depending on the sedimentation conditions, some are richer in one component, usually iron. Krauskopf (1957) emphasizes that the oxidations $\mathrm{Fe}^{2+} \longrightarrow \mathrm{Fe}^{3+}$ and $\mathrm{Mn}^{2+} \longrightarrow \mathrm{Mn}^{4+}$ are slow reactions. A 

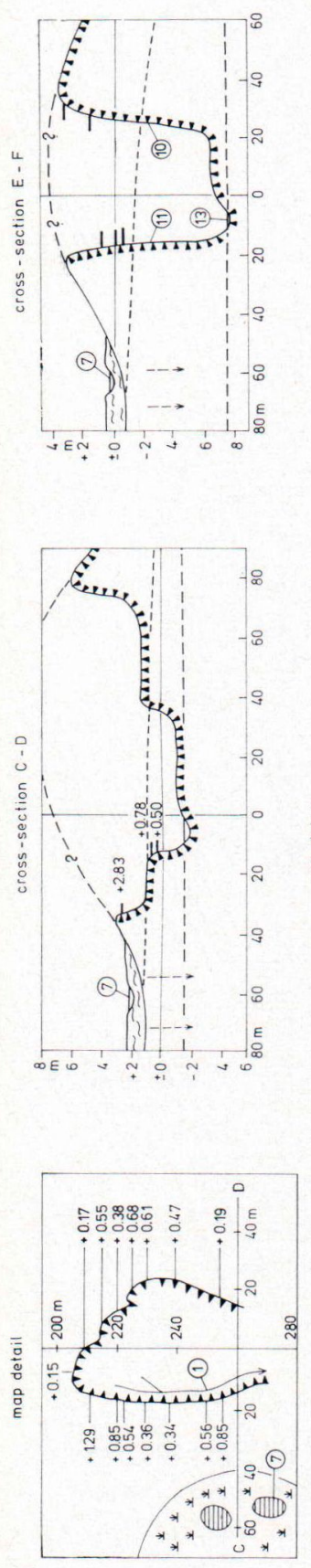

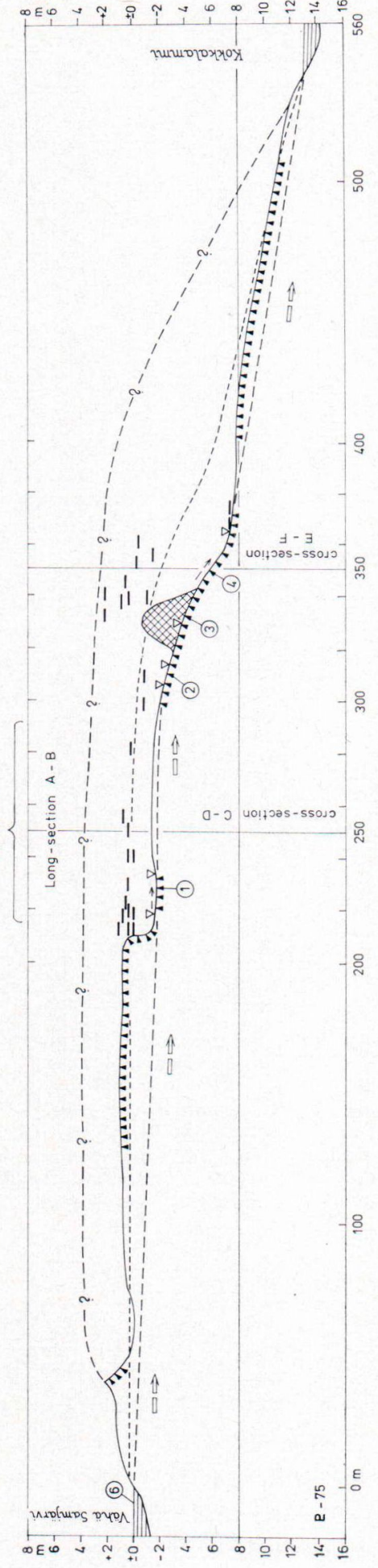

slow oxidation of iron seems to be the case in the sediments studied here, but the sharp contacts of manganese precipitates low in iron point to a fast precipitation of manganese.

Precipitation in eskers from fast flowing groundwater cannot be brought about by bacteria or higher vegetation. Rather, the process can be supposed to be the following. Femic minerals containing $\mathrm{Fe}$ and $\mathrm{Mn}$ are dissolved by organic acids in the soil. Cations, excluding alkalis, migrate as dissolved complex compounds (cf. Koljonen and Carlson 1975). Mn-complexes are as stable as Fe-complexes and are broken down, more than Fe-complexes, by oxidation in sediments where the $\mathrm{pH}$ is higher owing to the hydrolysis of minerals. The $\mathrm{Fe} / \mathrm{Mn}$-ratio in the silicic plutonic rocks of Central Finland is 107 (op. cit., Table 1). Fe dominates in groundwater, but the $\mathrm{Fe} / \mathrm{Mn}$-ratio decreases because part of the iron is precipitated into sediments and especially into B-horizon in podzol when $\mathrm{pH}-\mathrm{Eh}$ conditions are suitable for oxidation and precipitation of the iron which is not complex-bound. Fe/Mn-ratio in groundwater is about 25:1 (Table 3). Mn migrates in sediments as $\mathrm{Mn}^{2+}$ or as unstable inorganic complexes, e.g., $\mathrm{MnHCO}_{3}{ }^{+}$(Hem 1963). Wher. suitable $\mathrm{pH}-\mathrm{Eh}$ conditions allow, $\mathrm{Mn}$ is oxidized fast and precipitated, though inorganic processes usually lead to the pre-

Fig. 3. The levelled profiles of gravel pits in the studied esker. Symbols as in Fig. 2. The long profile $\mathrm{A}-\mathrm{B}$ is levelled between the ponds Vähä Samjärvi and Kokkalammi. At points $260 \mathrm{~m}$ and $360 \mathrm{~m}$, short cross profiles $\mathrm{C}-\mathrm{D}$ and $\mathrm{E}-\mathrm{F}$ are depicted and a plan detail is drawn for the area between points $200 \mathrm{~m}$ and $280 \mathrm{~m}$. The profiles show the present ground level and groundwater table and the estimated levels before the removal of sand and gravel. The water table (the height of which naturally varies according to the season) dips along the ridge towards Kokkalammi (cf. broken arrows). 
Table 2. Chemical compositions of the precipitates $\left(110^{\circ} \mathrm{C}\right) .1$. Loose, needle-like manganiferous powder accumulated into cavities in gravel (cf. Fig. 5). The powder is probably recrystallized precipitate which has dissolved from the surrounding cement; 2. Hard, manganiferous precipitate which for years has been exposed to air. It forms a horizontal band about $10 \mathrm{~cm}$ thick and several meters long on a nearly vertical rock face. The original layer was broken when gravel was removed; $3 \mathrm{a}$. Hard, aged manganiferous horizon exposed to air high on the wall of the gravel pit above the ferruginous horizon $3 \mathrm{~b}$ (cf. Fig. 4); 4 a. Loose, manganiferous precipitate recently deposited from groundwater discharge on the bottom of the gravel pit (cf. Fig. 6), and ferruginous precipitate $4 \mathrm{~b}$ around it.

\begin{tabular}{|c|c|c|c|c|c|c|}
\hline & 1 & 2 & $3 a$ & $3 \mathrm{~b}$ & $4 \mathrm{a}$ & $4 \mathrm{~b}$ \\
\hline $\begin{array}{l}\mathrm{Mn} \% \\
\mathrm{Fe} \\
\mathrm{Al} \\
\mathrm{Mg} \\
\mathrm{Ca} \\
\mathrm{K} \\
\mathrm{Na}\end{array}$ & $\begin{array}{r}43.79 \\
3.85 \\
0.91 \\
0.58 \\
1.26 \\
0.82 \\
0.18\end{array}$ & $\begin{array}{r}41.02 \\
6.39 \\
3.77 \\
1.84 \\
0.44 \\
2.79 \\
0.46\end{array}$ & $\begin{array}{r}26.47 \\
10.84 \\
7.23 \\
4.81 \\
0.35 \\
3.15 \\
0.31\end{array}$ & $\begin{array}{r}0.35 \\
27.10 \\
11.14 \\
5.20 \\
0.89 \\
4.15 \\
0.59\end{array}$ & $\begin{array}{r}18.39 \\
14.10 \\
8.84 \\
11.67 \\
0.55 \\
4.49 \\
0.43\end{array}$ & $\begin{array}{r}0.67 \\
27.47 \\
10.83 \\
5.69 \\
0.55 \\
5.36 \\
0.41\end{array}$ \\
\hline $\begin{array}{l}\mathrm{Li} \text { ppm } \\
\mathrm{Zn} \\
\mathrm{Cu} \\
\mathrm{Co} \\
\mathrm{Ni}\end{array}$ & $\begin{array}{c}25 \\
3378 \\
926 \\
560 \\
0.2\end{array}$ & $\begin{array}{r}65 \\
913 \\
216 \\
70 \\
<280\end{array}$ & $\begin{array}{r}88 \\
895 \\
481 \\
160 \\
<320\end{array}$ & $\begin{array}{r}96 \\
1136 \\
290 \\
140 \\
<290\end{array}$ & $\begin{array}{r}86 \\
1233 \\
398 \\
130 \\
<330\end{array}$ & $\begin{array}{r}122 \\
711 \\
317 \\
200 \\
<160\end{array}$ \\
\hline
\end{tabular}

Table 3. Chemical composition of ground- and surface water in the studied area. The sampling sites are shown in Figs. 2 and 3. The groundwater discharging from the bottom of the pit is slightly acidic and $\mathrm{Mn}$ and $\mathrm{Fe}$ content in water are low and differ in various parts of the pit (Nos. 1-4). The surface water and especially bog water (Nos. 6-7) contains less electrolytes but more humus than groundwater. The short line means no determination.

\begin{tabular}{|c|c|c|c|c|c|c|c|c|c|c|}
\hline No. and site of samples & $\mathrm{pH}$ & $\begin{array}{l}\text { Sp. con- } \\
\text { ductivity } \\
\mu \mathrm{S} / \mathrm{cm} \\
\left(+20^{\circ} \mathrm{C}\right)\end{array}$ & $\begin{array}{c}\text { Alka- } \\
\text { linity } \\
\text { meq. }\end{array}$ & \begin{tabular}{|c|} 
Total \\
hard- \\
ness \\
$\mathrm{dH}^{0}$
\end{tabular} & $\left|\begin{array}{c}\mathrm{KMnO}_{4^{-}} \\
\text {con- } \\
\text { sumption } \\
\mathrm{mg} / 1\end{array}\right|$ & $\begin{array}{c}\mathrm{Ca} \\
\mathrm{ppm}\end{array}$ & $\begin{array}{c}\mathrm{Mg} \\
\mathrm{ppm}\end{array}$ & $\begin{array}{c}\mathrm{Fe} \\
\mathrm{ppm}\end{array}$ & $\begin{array}{l}\mathrm{Mn} \\
\mathrm{ppm}\end{array}$ & $\begin{array}{c}\mathrm{Al} \\
\mathrm{ppm}\end{array}$ \\
\hline $\begin{array}{l}\text { 1. Groundwater discharge in } \\
\text { a gravel pit (Fig. } 3 \text { ) }\end{array}$ & 5.91 & 93 & 0.24 & 2.1 & 7.9 & 10.5 & 2.9 & 4.00 & 0.25 & 2.7 \\
\hline $\begin{array}{l}\text { 2. Groundwater discharge in } \\
\text { a gravel pit (Figs. } 3 \text { and } 6 \text { ) }\end{array}$ & 5.64 & 116 & 0.16 & 2.0 & 6.5 & 7.0 & 3.4 & 0.83 & 0.03 & 0.2 \\
\hline 3. Groundwater discharge in & 6.31 & 72 & 0.33 & 1.8 & 7.6 & 10.7 & 2.9 & 4.44 & 0.18 & - \\
\hline $\begin{array}{l}\text { 4. Brook in a gravel pit } \\
\text { (Fig. 3) } \\
\text { 5. Well with concrete }\end{array}$ & 6.19 & 107 & 0.20 & 2.2 & - & 10.7 & 2.9 & - & - & 1.8 \\
\hline $\begin{array}{l}\text { casing (Fig. 2) } \\
\text { 6. The pond Vähä Samjärvi }\end{array}$ & 6.28 & 114 & 0.20 & 2.1 & 5.8 & 11.8 & 2.1 & 1.42 & 0.15 & - \\
\hline $\begin{array}{l}\text { (Fig. } 2 \text { ) } \\
\text { 7. Surface water from a }\end{array}$ & 6.64 & 45 & 0.15 & 1.2 & 17.0 & 5.3 & 1.8 & 0.07 & $<0.005$ & - \\
\hline $\begin{array}{l}\text { small bog (Fig. 3) } \\
\text { 8. A ditch (Fig. 2) }\end{array}$ & $\begin{array}{l}4.79 \\
579\end{array}$ & 26 & 0.03 & 0.8 & 68.6 & 1.8 & 2.5 & 0.50 & 0.005 & 0.4 \\
\hline & & & 0.16 & 2.3 & 9.8 & 12.6 & 2.2 & 2.5 & 0.005 & - \\
\hline
\end{tabular}

cipitation of Fe before Mn unless the content of the latter in solution is very high. However, Fe is more tightly bound in complexes than $\mathrm{Mn}$ and is not oxidized as fast as $\mathrm{Mn}$.
Hence Mn-rich precipitates are formed first. Angular grain faces and earlier Mn-precipitates support precipitation but are not necessary to it. 
Bulletin of the Geological Society of Finland, No. 48, 1976.

\section{E R R A T A}

Page 120, Table 4, ppm ought to be ppb as follows

\begin{tabular}{c|r|r|r|r}
\hline No. of samples & $\begin{array}{r}\mathrm{Zn} \\
\mathrm{ppb}\end{array}$ & $\begin{array}{c}\mathrm{Cu} \\
\mathrm{ppb}\end{array}$ & $\begin{array}{c}\mathrm{Co} \\
\mathrm{ppb}\end{array}$ & $\begin{array}{c}\mathrm{Ni} \\
\mathrm{ppb}\end{array}$ \\
\hline & & & & \\
9 & 22 & 7 & 4 & 6 \\
10 & 17 & 1 & $<2$ & $<2$ \\
11 & 100 & 28 & 13 & 15 \\
12 & 17 & 2 & 4.5 & 5 \\
13 & 7 & 2 & 2.5 & $<2$ \\
\hline
\end{tabular}


Table 4. Zn, $\mathrm{Cu}, \mathrm{Co}$, and $\mathrm{Ni}$ contents in 5 water samples from the studied area. After the investigation of the site an earth dam was built in the narrow passage between the upper and lower parts of the pit $(300-350 \mathrm{~m}$ in the longsection $\mathrm{A}-\mathrm{B}$, cf. Figs. 2 and 3 ). As a result of this the water table has risen a couple of meters to about the estimated level of the earlier water table. Sampling sites are indicated in Figs. 2 and 3 . Only the samples for heavy metal analysis (this table) were collected after damming. 9. Water on the bottom of the pit; $10-13$. Groundwater discharging from the bottom and walls of the pit below the dam. The sample of groundwater discharging near the small peat bog (No. 11) contains more heavy metals than samples from other parts of the pit. Both in precipitates (Table 2) and in groundwater the contents of $\mathrm{Zn}$ are greater than $\mathrm{Cu}, \mathrm{Ni}$, and $\mathrm{Co}$.

\begin{tabular}{c|r|r|r|r}
\hline No. of samples & $\begin{array}{l}\mathrm{Zn} \\
\mathrm{ppm}\end{array}$ & $\begin{array}{l}\mathrm{Cu} \\
\mathrm{ppm}\end{array}$ & $\begin{array}{l}\mathrm{Co} \\
\mathrm{ppm}\end{array}$ & $\begin{array}{l}\mathrm{Ni} \\
\mathrm{ppm}\end{array}$ \\
\hline & & & & \\
9 & 22 & 7 & 4 & 6 \\
10 & 17 & 1 & $<2$ & $<2$ \\
11 & 100 & 28 & 13 & 15 \\
12 & 17 & 2 & 4.5 & 5 \\
13 & 7 & 2 & 2.5 & $<2$ \\
\hline
\end{tabular}

Fe may be oxidized later in small rivulets and ponds (Fig. 6). This process is especially promoted by organisms that thrive in sluggish water, in sunshine, and under atmospheric conditions. Possibly the precipitation of $\mathrm{Fe}$ is brought about by the decomposition of the organic part of the complex. In waters rich in organisms, $\mathrm{Mn}$ seems to $\mathrm{mi-}$ grate easily. In organic-rich milieu $\mathrm{Mn}$ is in dissolved form or incorporated into organisms as trace nutrient, whereas $\mathrm{Fe}$ is largely removed as hydroxide (cf. Koljonen and Carlson 1975). If aerated waters are utilized in water supply, $\mathrm{Mn}$ is precipitated, harmfully, in wells and in pipes through which water flows fast and where conditions are not favorable for organic life.

$\mathrm{Al}, \mathrm{Mg}$, and $\mathrm{K}$, and many trace elements are coprecipitated with oxidates (Table 2).

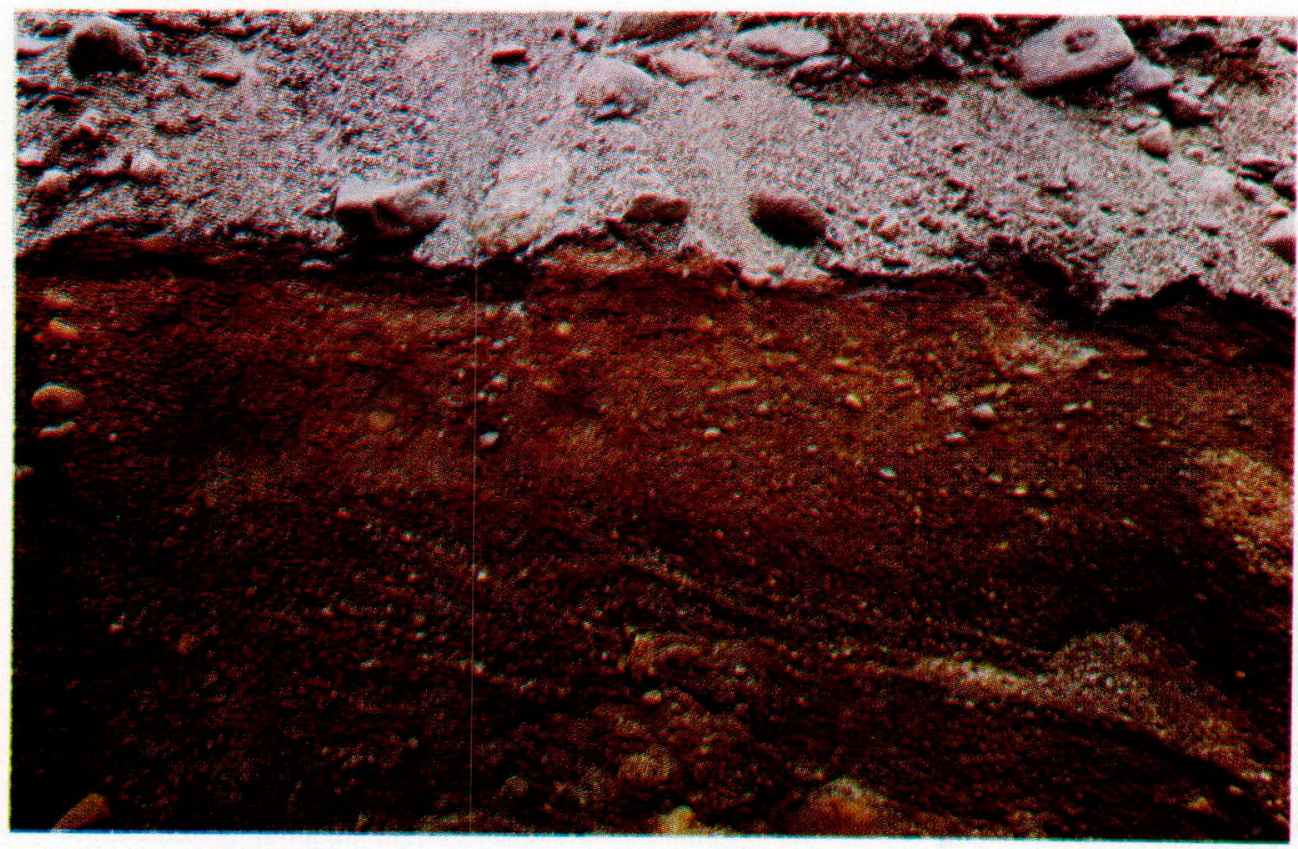

Fig. 4. A photo of aged manganiferous and ferruginous precipitates in stratified sand and gravel. Thin horizontal Mn-rich belt of precipitate (black) above thick zone of ferruginous precipitate (brown) on the wall of the gravel pit (the highest position, $340 \mathrm{~m}$ in Fig. 3) (type a in Fig. 1 and Table 1 ; Nos. $3 \mathrm{a}$ and $\mathrm{b}$ in Table 2). 


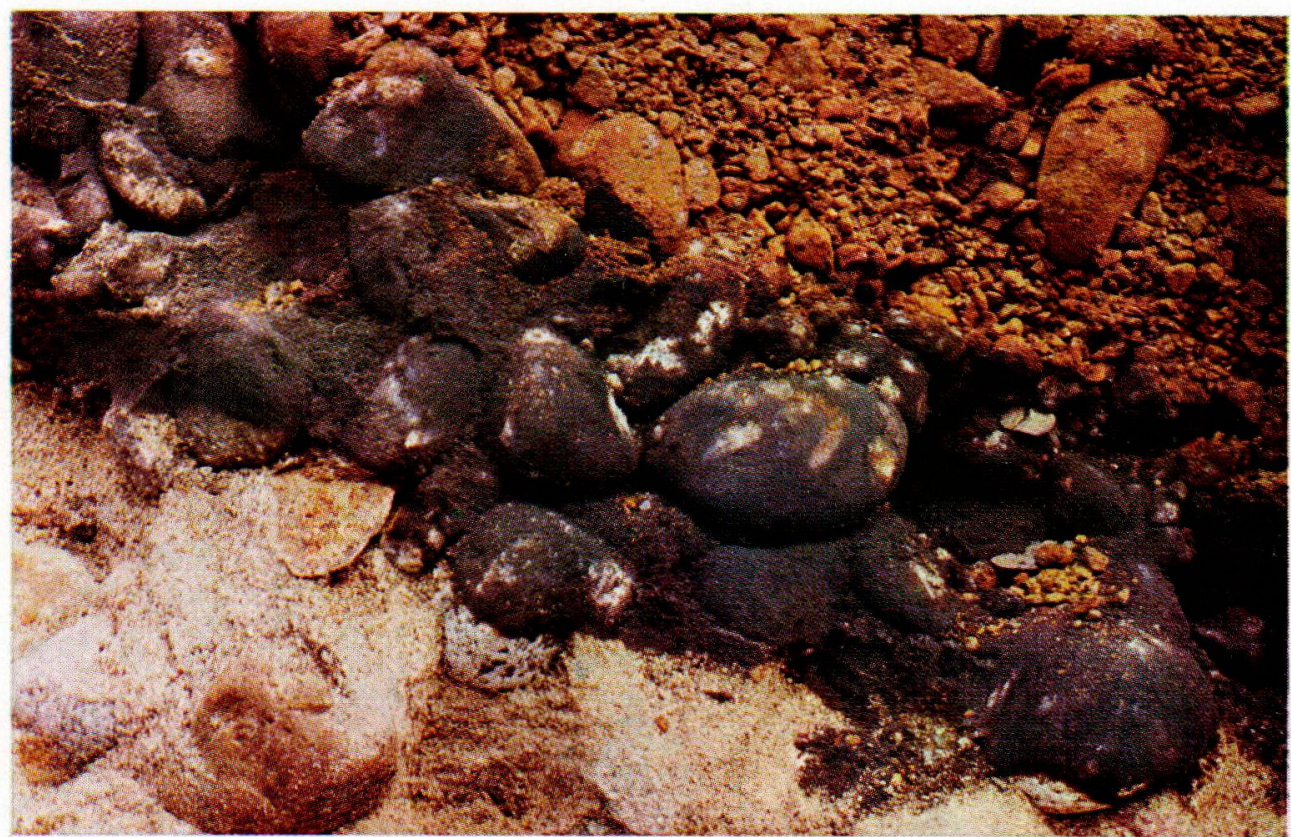

Fig. 5. A photo of manganese-rich precipitate (black) on an inclined sheet of stony gravel (type $\mathrm{f}$ in Fig. 1 and Table 1; No. 1 in Table 2). The groundwater table was at the level of the zone of precipitates until the utilization of material a few years ago.

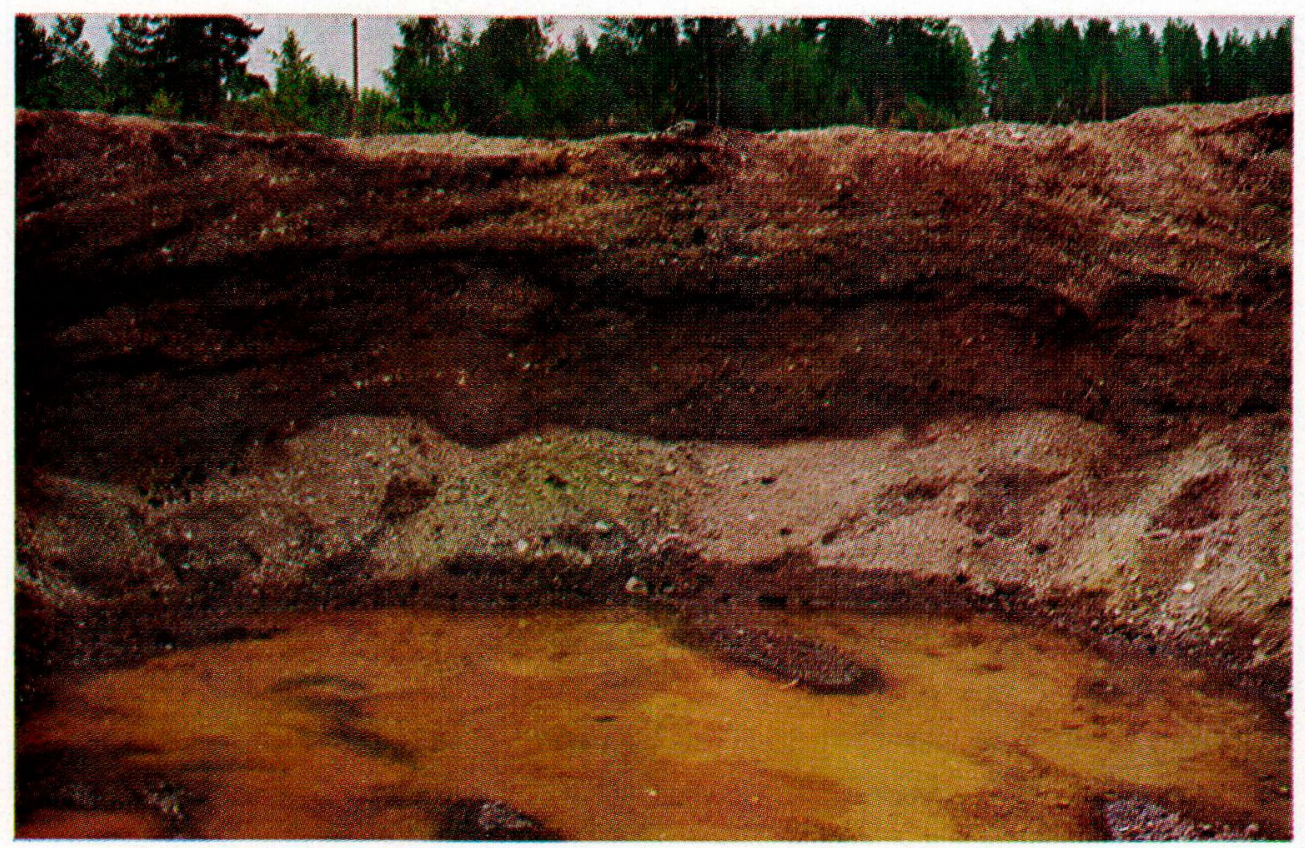

Fig. 6. A photo of recent ferruginous precipitate in a shallow pond formed by groundwater discharging on the bottom of a gravel pit. In the background there are Fe- and Mn-precipitates representing earlier positions of the groundwater table as it descended during utilization of material. 
The precipitation of other major elements as cement is not as conspicuous as that of $\mathrm{Fe}$ and $\mathrm{Mn}$ because their hydroxides are colorless, and they separate during the process and settle in different sites usually as hydrolyzates.

\section{Experimental}

A Philips diffractometer using Mn-filtered Fe-radiation and equipped with a wide-angle goniometer was used to identify the minerals in manganiferous and ferruginous precipitates. Manganiferous samples were scanned from 4 to $90^{\circ} 2 \Theta$ and ferruginous samples from 4 to $75^{\circ}$ at a scanning speed of $1 / 2^{\circ} 2 \Theta /$ min. Internal silicion was used as standard and results were recorded as graphs (Figs. 7 -10, Tables 5-10).

To concentrate the minerals in precipitates the sample was stirred with water. Three fractions were decanted and dried at $50^{\circ} \mathrm{C}$. The finest was mostly amorphous and the coarsest contained disturbing amounts of detrital minerals typical of the surrounding bedrock (quartz, feldspars, mica, etc.). The middle fraction contained some mica but was used for the mineral analysis since mica does not interfere with the identification.

Dried fractions were ground and a thin film of powder was spread with distilled water on a glass-slide for the analysis. The method may cause preferred orientation and have some effect on the intensities of reflections.

Samples were heated in a Heraeus muffle oven in air for $1-2 \mathrm{~h}$ at each temperature. The same material was heated stepwise to facilitate the interpretation of results. Glassslides were then prepared and the minerals identified.

\section{Manganiferous samples}

The reflections, usually four, of the manganese oxide $\delta-\mathrm{MnO}_{2}$ (McMurdie 1944), called manganous manganite (Feitknecht and Marti 1945) as synthetic and birnessite (Jones and Milne 1956) as mineral, were recorded for most of the samples (Figs. 7-10, Table 5). This mineral has been found in Mn-ores, usually as an alteration or weathering product (McMurdie and Golovato 1948; Frondel et al. 1960; Hariya 1961; Larson 1962; Levinson 1962; Sorem and Gunn 1967; Brown et al. 1971), in marine manganese nodules (Buser and Grütter 1956; Barnes 1967; Cronan and Tooms 1969; Finkelman et al. 1972; Glasby 1972; Finkelman et al. 1974), and in soils (Jones and Milne 1956; Taylor et al. 1964; Taylor and McKenzie 1966; Taylor 1968). Jones and Milne who assigned the name found it in a "manganese pan cutting in a fluvio-glacial deposit of gravel» in Scotland and, together with Li-bearing lithiophorite, it is the most common manganiferous mineral found in several different soils in Australia (Taylor et al. 1964). Birnessite is orthorhombic with $a_{0}=8.54, b_{0}=15.39$, and $c_{0}=14.26$ $\AA$ (Giovanoli et al. 1970).

Natural birnessite always contains small amounts of $\mathrm{Ca}, \mathrm{Na}, \mathrm{K}$, and other cations. Brown et al. (1971) give the chemical formula as $\mathrm{Ca}_{0.51} \mathrm{Na}_{0.54}\left(\mathrm{Mn}^{4+}{ }_{6.34} \mathrm{Mn}^{2+}{ }_{0.65}\right) \mathrm{O}_{14.1}$ $2.9 \mathrm{H}_{2} \mathrm{O}$.

Even small amounts of foreign cations present as weathering products in soils prevent the formation of $\mathrm{Mn}$-oxides which otherwise would crystallize, and favor the formation of birnessite and lithiophorite (McKenzie 1972). Birnessite crystallizes mostly in alkaline and neutral soils and lithiophorite in acid (Taylor et al. 1964).

In the samples studied the intensity and 
Table 5. Diffraction data of birnessite according to Jones and Milne (1956), Brown et al. (1971), and this study. Determined d-values are averages of 4 samples and the intensity values are based on the areas of the peaks in the graph (Figs. $7,8,9 \mathrm{a}$, and $10 \mathrm{a}$ ).

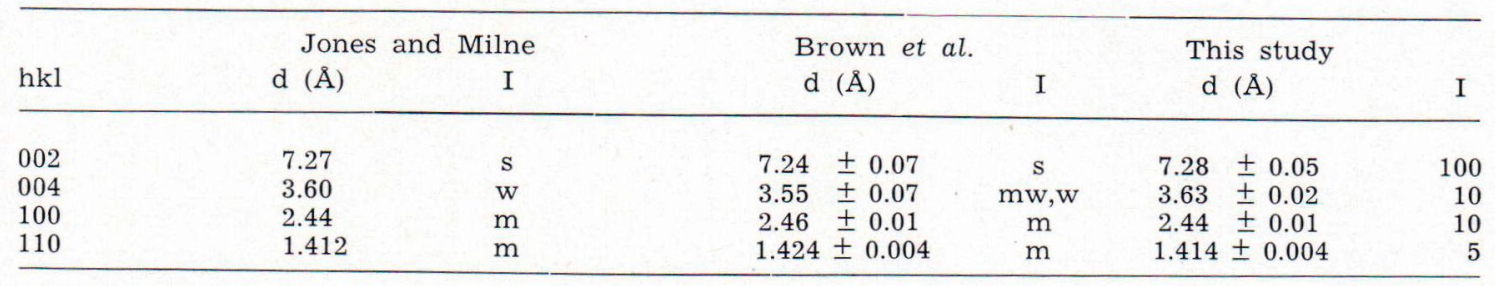

s, strong

$\mathrm{m}$, medium

mw, medium weak

$\mathrm{w}$, weak

broadness of the reflections of birnessite varied from sample to sample (Figs. 7, 8, 9 a, and $10 \mathrm{a})$. The orientation of platy crystals during preparation may be due to the higher average intensity of basal reflections in this study compared with the others. In sample 4 a (Table 2), which contains least Mn, only three of the four reflections were observed, and the strongest reflection, $7.2 \AA$, was extremely weak and borad. McMurdie's (1944) $\delta-\mathrm{MnO}_{2}$ gave only two reflections and Buser et al. (1954) suggest that highly oxidized forms do not give basal reflections (7.2 and $3.6 \AA$ ). Bricker (1965), on the other hand, explained the presence of basal reflections as a function of particle size rather than oxidation state. In this study the variation in particle size explains the greater variation in intensity of basal reflections than of the other two reflections from sample to sample. Taylor et al. (1964) estimate a particle size of c. 0.02 $\mu \mathrm{m}$ for soil birnessite from line broadening of the diffraction pattern. According to Brown et al. (1971) birnessite clusters on colemanite from Boron, California, are made up of thin, slightly bent lamellae, about $0.2 \mu \mathrm{m}$ thick at the edges.

Aging, dehydration, and high manganese content clearly improve the crystal structure of the precipitates. The best reflections were found for sample No. 1 (Table 2), taken from a cavity into which birnessite had recrystallized, and No. 2, which was the hardest cement and which had endured for years, exposed to air. When the content of foreign ions and especially iron increases (Nos. 3 a and $4 \mathrm{a}$ ) or the precipitate is young $(4 \mathrm{a})$ the birnessite crystals are small and the basal reflections are poor. Iron apparently impedes crystallization. Remarkably, no iron mineral is observed in manganese-rich cements.

The chemical composition of birnessite varies considerably. In the purest sample (No. 1) Ca was enriched. This supports the chemical formula presented by Brown et al. (1971), but composition is dependent on the surrounding sediments and in granitic areas potassium predominates over sodium, especially, because potassium is more strongly than sodium adsorbed on colloids (Koljonen and Carlson 1975). Based on the values recorded in Table 2, the formula of birnessite may be written as $(\mathrm{Ca}, \mathrm{K}, \mathrm{Na})(\mathrm{Mn}, \mathrm{Fe}, \mathrm{Al}$, $\mathrm{Mg}{ }_{7} \mathrm{O}_{14} \cdot \mathrm{nH}_{2} \mathrm{O}$.

\section{Ferruginous samples}

Two varieties of hydrated iron-oxide minerals occur (Rooksby 1972). These are poly- 


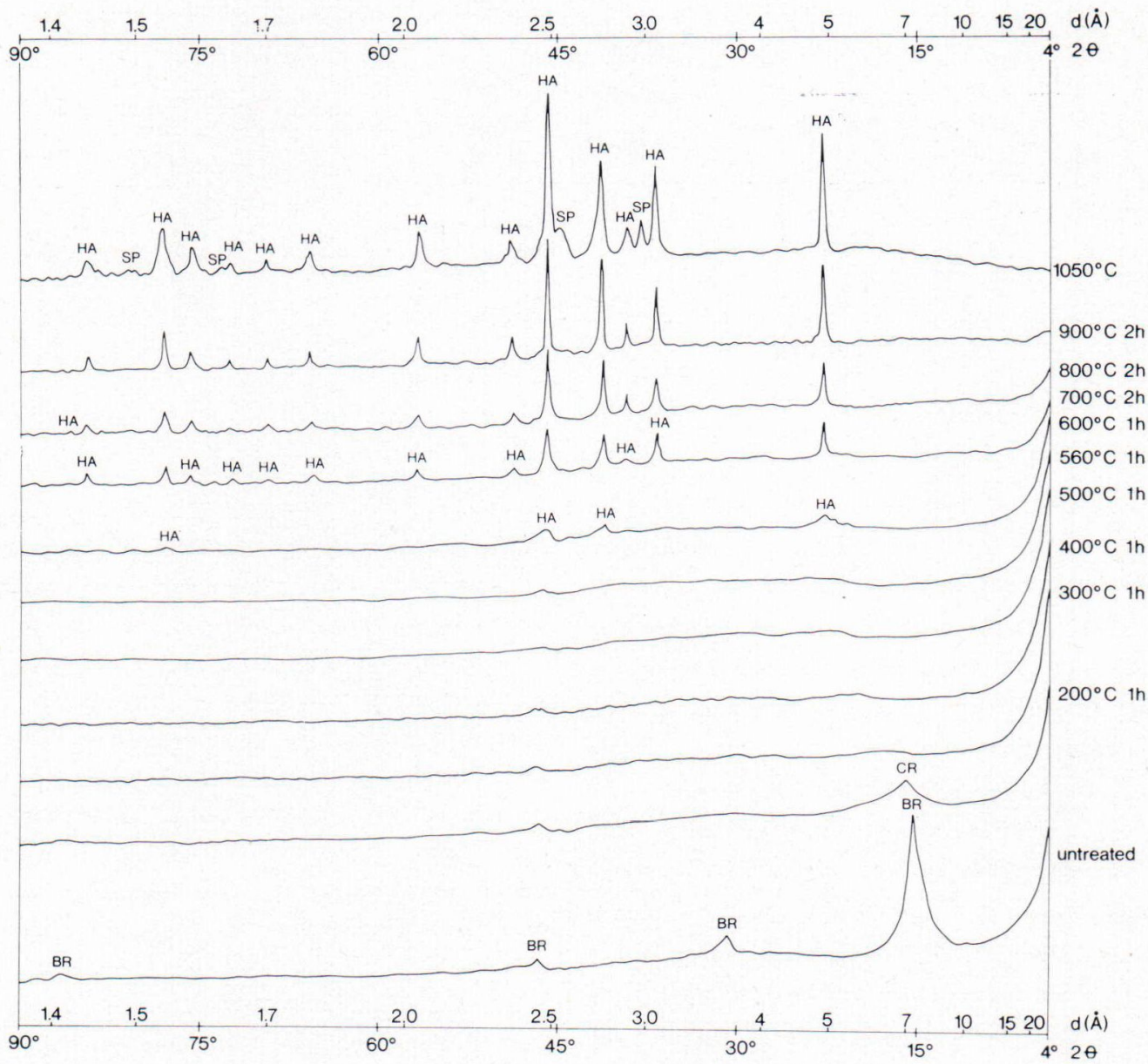

Fig. 7. X-ray data of unheated and heated manganiferous precipitate (Table 2, No. 1). Symbols: BR, birnessite; CR, cryptomelane; NS, nsutite; BX, bixbyite; HA, hausmannite; SP, spinel; G, goethite; L, lepidocrocite; M, maghemite; H, hematite; BT, biotite. The graphs are explained in text.

morphs of monohydrate $\mathrm{FeO}(\mathrm{OH})$, goethite and lepidocrocite, the $\alpha$ - and $\gamma$-ferric oxide monohydrates, respectively. Goethite is the crystal form produced from aging sols and gels of hydrous basic ferric oxide. It is orthorhombic with $a_{0}=4.596, b_{0}=9.957$, and $c_{0}=3.021 \AA$ (JCPDS 17-536). Lepidocrocite, which is formed through oxidation of ferrous compounds, is also orthorhombic, with $a_{0}=$ 3.87, $b_{0}=12.51$, and $c_{0}=3.06 \AA$ (Bernal et al. 1959). Powdered goethite is yellow and lepi- docrocite brown. Some modification in intensity of color is attributable to particle size (Birnbaum et al. 1947), but the shade depends on crystal form alone (Bunn 1941). In powdered form, the two samples here were yellowish brown (Figs. $9 \mathrm{~b}$ and $10 \mathrm{~b}$ ) and mixtures of goethite (Table 6) and lepidocrocite (Table 7).

Lepidocrocite dominated in sample $3 \mathrm{~b}$. The reflections were sharp and strong (Fig. 9 b) because aged and dried precipitates are 


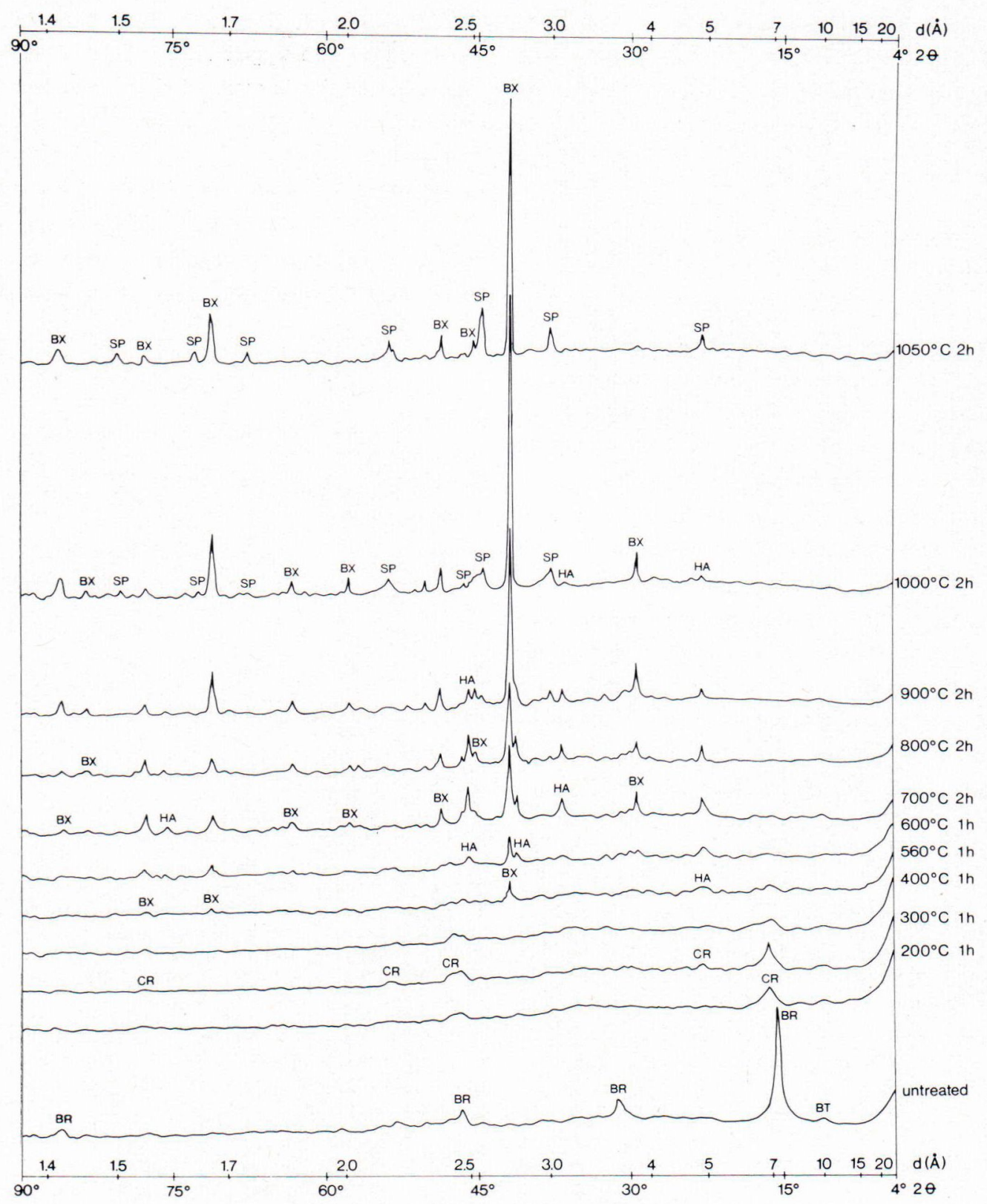

Fig. 8. X-ray data of unheated and heated manganiferous precipitate (Table 2, No. 2). Symbols as in Fig. 7. The graphs are explained in text.

better crystallized than newly formed ones (cf. sample $4 \mathrm{~b}$ in Fig. $10 \mathrm{~b}$ ). The ratio of the intensity of the strongest reflection of lepidocrocite to that of goethite was 1.7 in No. $3 \mathrm{~b}$
(Table 2), while in sample 4 b (Table 2) it was 0.3 . The reflections of goethite were broad and diffuse in both samples even though intensities varied. According to Norrish 
and Taylor (1961) this is typical of soil goethites and not only due to small crystal size but to the superposition of slightly different patterns.

\section{Recrystallization of manganiferous} precipitates upon heating

Birnessite is not stable when heated: depending on temperature and the duration of the heating process, it either recrystallizes as cryptomelane $\left(\alpha-\mathrm{MnO}_{2}\right)$ or nsutite $\left(\gamma-\mathrm{MnO}_{2}\right)$ (Jones and Milne 1956) or decomposes to amorphous form. Synthetic birnessite with low potassium content was found to convert to nsutite on boiling, but cryptomelane $\left(\mathrm{KMn}_{8} \mathrm{O}_{16}\right)$ formed when the $\mathrm{K}$ content was over c. $1 \%$ (Buser et al. 1954). Birnessite with a potassium content of $9.4 \%$ remained unchanged after boiling for $24 \mathrm{~h}$ but converted to cryptomelane after being heated for $60 \mathrm{~h}$ at $400^{\circ} \mathrm{C}$ (McKenzie 1971). The

Table 6. Diffraction data of goethite according to Rooksby (1972) and as recorded here. Determined d-values are from sample $3 \mathrm{~b}$ (Fig. $9 \mathrm{~b}$ ), and the intensities are based on the areas of peaks in the graph.

\begin{tabular}{llrcr}
\hline \multicolumn{3}{c}{ Rooksby } & \multicolumn{2}{c}{ This study } \\
hkl & $\mathrm{d}(\AA)$ & \multicolumn{1}{c}{$\mathrm{I}$} & $\mathrm{d}(\AA)$ & $\mathrm{I}$ \\
\hline & & & & \\
020 & 4.98 & 15 & $4.998 \pm 0.02$ & 15 \\
110 & 4.18 & 100 & $4.195 \pm 0.02$ & 100 \\
120 & 3.38 & 10 & & \\
130 & 2.69 & 30 & $2.694 \pm 0.005$ & 30 \\
021 & 2.58 & 8 & $2.580 \pm 0.005$ & 10 \\
101 & 2.520 & 3 & & \\
040 & 2.490 & 15 & $2.500 \pm 0.008$ & 15 \\
111 & 2.452 & 25 & $2.444 \pm 0.003$ & 40 \\
121 & 2.252 & 10 & $2.242 \pm 0.004$ & 15 \\
140 & 2.192 & 20 & $2.186 \pm 0.004$ & 10 \\
131 & 2.009 & 2 & & \\
041 & 1.920 & 6 & & \\
211 & 1.799 & 7 & & \\
141 & 1.770 & 2 & & \\
221 & 1.721 & 20 & $1.723 \pm 0.002$ & 10 \\
\hline
\end{tabular}

cryptomelane contained c. $7 \% \%$ K, which seems to be the upper limit. The ease with which birnessite is converted to cryptomelane also appears to depend on the crystal form. Needle-like birnessite crystals recrystallized to bigger cryptomelane crystals more easily than platy crystals did. Platy birnessite crystals gave rise to mixtures: more birnessite than cryptomelane on boiling and more

Table 7. Diffraction data of lepidocrocite according to Rooksby (1972) and as recorded in this study. Determined d-values are from sample $3 \mathrm{~b}$ (Fig. $9 \mathrm{~b})$, and the intensities are based on the areas of peaks in the graph.

\begin{tabular}{|c|c|c|c|c|}
\hline hkl & Rooksby & I & \multicolumn{2}{|c|}{ This study } \\
\hline 020 & 6.27 & 100 & $6.226 \pm 0.02$ & 100 \\
\hline 021 & 3.29 & 60 & $3.280 \pm 0.005$ & 40 \\
\hline 130 & 2.473 & 30 & $2.469 \pm 0.002$ & 24 \\
\hline 111 & 2.362 & 15 & & \\
\hline 131 & 2.086 & 12 & & \\
\hline 150,002 & 1.935 & 30 & $1.936 \pm 0.002$ & 10 \\
\hline 022 & 1.848 & 10 & & \\
\hline 151 & 1.733 & 15 & & \\
\hline
\end{tabular}

Table 8. Diffraction data of bixbyite according to JCPDS card 10-69 (synthetic material) and as recorded here. Determined d-values are averages of three samples and the intensities are based on the areas of peaks in the graph (Figs. 8, $9 \mathrm{a}$, and 10 a).

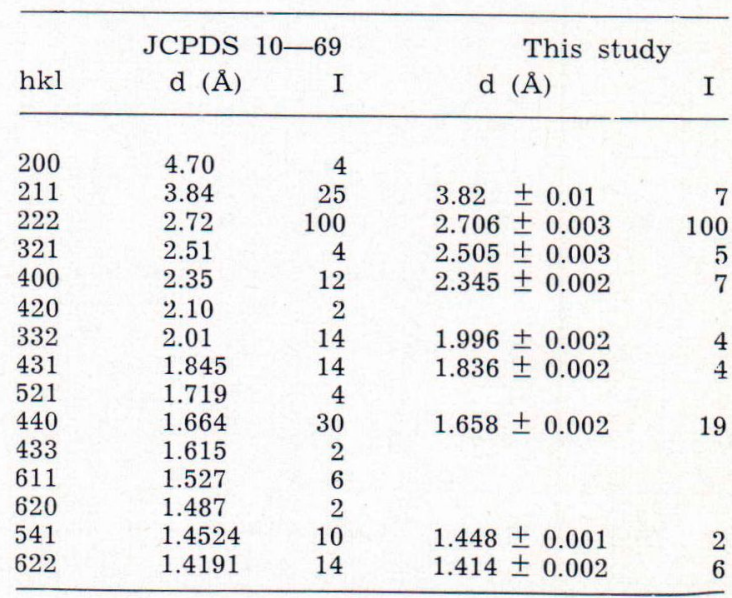


cryptomelane than birnessite on heating (McKenzie 1971).

Synthetic $\delta-\mathrm{MnO}_{2}$, crystallized as pyrolusite $\left(\beta-\mathrm{MnO}_{2}\right)$ at $300^{\circ} \mathrm{C}$, as bixbyite $\left(\mathrm{Mn}_{2} \mathrm{O}_{3}\right)$ at c. $500^{\circ} \mathrm{C}$, and as hausmannite at c. $900^{\circ} \mathrm{C}$ (Klingsberg and Roy 1959). $\gamma-\mathrm{MnO}_{2}$ converted to bixbyite at c. $450^{\circ} \mathrm{C}$.

According to McKenzie (1972), the formation of nsutite and pyrolusite in soils is pre-

Table 9. Diffraction data of hausmannite according to JCPDS card 16-154 and as recorded in this study. Determined d-values are averages of four samples and the intensities are based on the areas of peaks in the graph (Figs. 7, 8, 9 a and 10 a).

\begin{tabular}{lcrlr}
\hline & \multicolumn{2}{c}{ JCPDS } & $16-154$ & \multicolumn{2}{c}{ This study } \\
hkl & $\mathrm{d}(\AA)$ & $\mathrm{I}$ & $\mathrm{d}(\AA)$ & $\mathrm{I}$ \\
\hline & & & & \\
001 & 4.94 & 30 & $4.89 \pm 0.02$ & 50 \\
112 & 3.09 & 50 & $3.07 \pm 0.01$ & 35 \\
020 & 2.89 & 30 & $2.874 \pm 0.005$ & 13 \\
013 & 2.77 & 90 & $2.744 \pm 0.010$ & 65 \\
121 & 2.49 & 100 & $2.482 \pm 0.005$ & 100 \\
004 & 2.36 & 40 & $2.340 \pm 0.004$ & 10 \\
220 & 2.04 & 40 & $2.033 \pm 0.003$ & 16 \\
024 & 1.825 & 20 & $1.818 \pm 0.001$ & 5 \\
015 & 1.795 & 50 & $1.782 \pm 0.004$ & 10 \\
132 & 1.706 & 30 & $1.696 \pm 0.001$ & 5 \\
033 & 1.642 & 20 & $1.638 \pm 0.001$ & 5 \\
231 & 1.579 & 50 & $1.575 \pm 0.002$ & 15 \\
224 & 1.544 & 80 & $1.536 \pm 0.002$ & 30 \\
116 & 1.468 & 10 & & \\
134,040 & 1.445 & 40 & $1.439 \pm 0.003$ & 10 \\
\hline
\end{tabular}

Table 10. Diffraction data of hematite according to Rooksby (1972) and as recorded in this study. Determined d-values are averages of two samples (Figs. $9 \mathrm{~b}$ and $10 \mathrm{~b}$ ) and the intensities are based on the areas of peaks in the graph.

\begin{tabular}{llrcr}
\hline \multicolumn{3}{c}{ Rooksby } & \multicolumn{2}{c}{ This study } \\
hkl & $\mathrm{d}(\AA)$ & $\mathrm{I}$ & $\mathrm{d}(\AA)$ & $\mathrm{I}$ \\
\hline & & & & \\
102 & 3.67 & 35 & $3.665 \pm 0.010$ & 45 \\
104 & 2.69 & 100 & $2.691 \pm 0.004$ & 100 \\
110 & 2.514 & 75 & $2.510 \pm 0.004$ & 75 \\
113 & 2.204 & 25 & $2.200 \pm 0.003$ & 20 \\
202 & 2.072 & 3 & & \\
204 & 1.838 & 30 & $1.836 \pm 0.003$ & 24 \\
116 & 1.692 & 45 & $1.691 \pm 0.002$ & 30 \\
121 & 1.635 & 2 & & \\
108 & 1.597 & 15 & $1.594 \pm 0.002$ & 10 \\
\hline
\end{tabular}

vented by the presence of foreign ions; large amounts prevent the formation of nsutite and even small amounts the formation of pyrolusite. Heating of pure birnessite produced first nsutite and then pyrolusite, but birnessite containing large amount of cations such as $\mathrm{Na}, \mathrm{K}, \mathrm{Ca}$, and $\mathrm{Ba}$ converted directly to cryptomelane.

Hariya (1961) heated natural birnessite for $1 \mathrm{~h}$ at $150^{\circ} \mathrm{C}$ and found that the intensities of X-ray reflections decreased. After $1 \mathrm{~h}$ at $300^{\circ} \mathrm{C}$ the material was almost amorphous. Hausmannite crystallized at $560^{\circ} \mathrm{C}$. In the experiments of Brown et al. (1971), natural birnessite changed to cryptomelane and then crystallized as hausmannite at $600^{\circ} \mathrm{C}$ after passing through an amorphous state. Glemser et al. (1961) observed that birnessite containing foreign cations lost water at $110-125^{\circ} \mathrm{C}$ and converted to cryptomelane at $370-500^{\circ} \mathrm{C}$ and to bixbyite upon further heating. McMurdie and Golovato (1948) report that cryptomelane may convert directly to hausmannite or go through an intermediate stage of bixbyite because of impurities. Natural cryptomelane was found to convert to bixbyite upon heat treatment for $5 \mathrm{~h}$ at $600^{\circ} \mathrm{C}$, but not totally (Faulring et al. 1960). After $17 \mathrm{~h}$ at $800^{\circ} \mathrm{C}$, bixbyite was the only mineral present. Hausmannite appeared as minor constituent after $1.5 \mathrm{~h}$ at $900^{\circ} \mathrm{C}$, and was the only constituent at $1000^{\circ} \mathrm{C}$ when heated $6^{\circ} / \mathrm{min}$. After the material had been ignited for $17 \mathrm{~h}$ at $900^{\circ} \mathrm{C}$, a phase with spinel structure was obtained, and after $48 \mathrm{~h}$ at $950^{\circ} \mathrm{C}$, spinel with $a_{0}=8.42$ $\AA$ was the only mineral observed. McMurdie and Golovato (1948) report a spinel with $a_{0}=8.7 \AA$ as the inversion product of hausmannite at $1170^{\circ} \mathrm{C}$.

The X-ray diffractograms of the heattreated manganiferous samples studied here are set out in Figs. $7-10$ and their chemical 


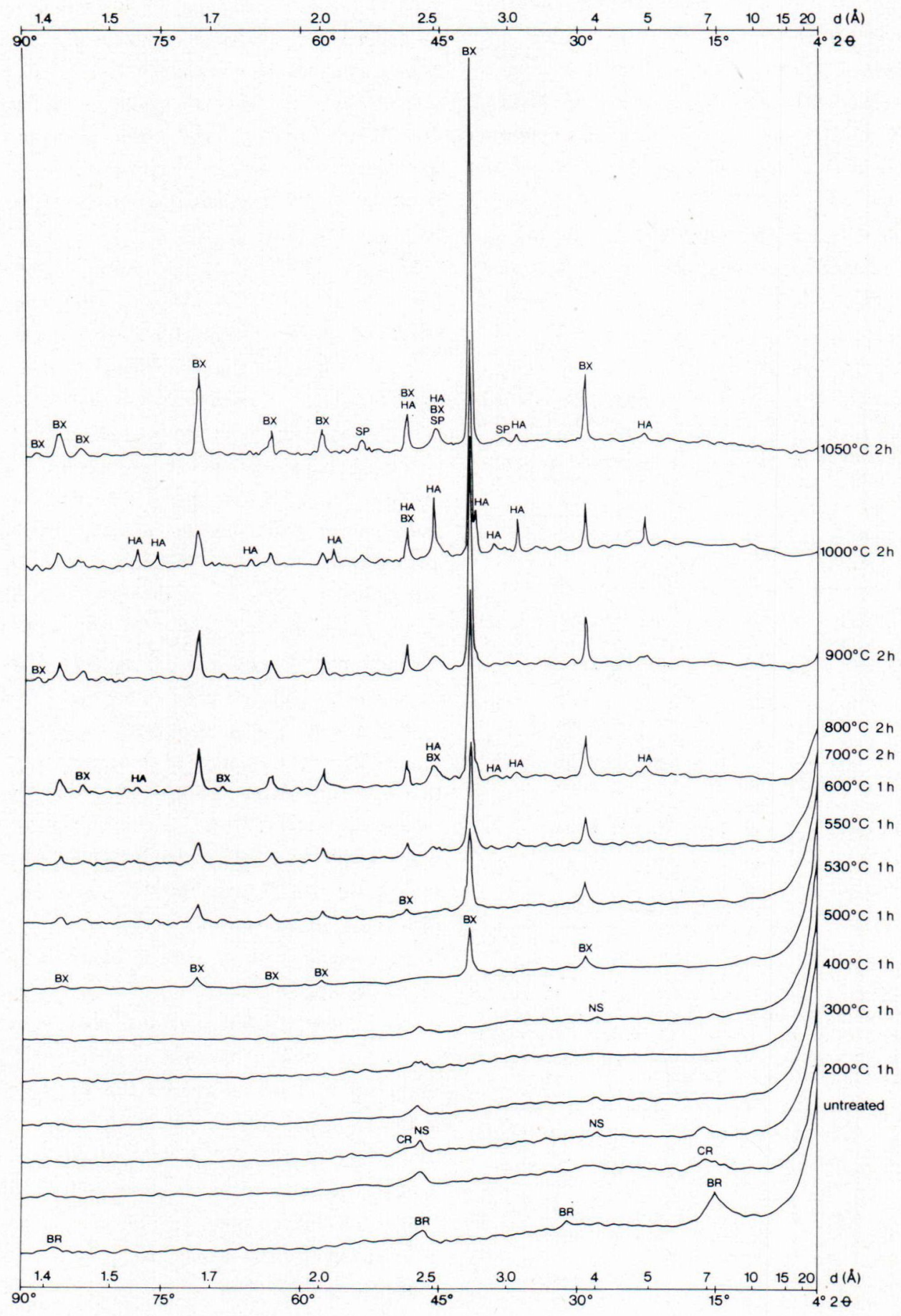

Fig. 9 a. X-ray data of unheated and heated manganiferous precipitate (Table 2, No. 3 a). Symbols as in Fig. 7. The graphs are explained in text. 


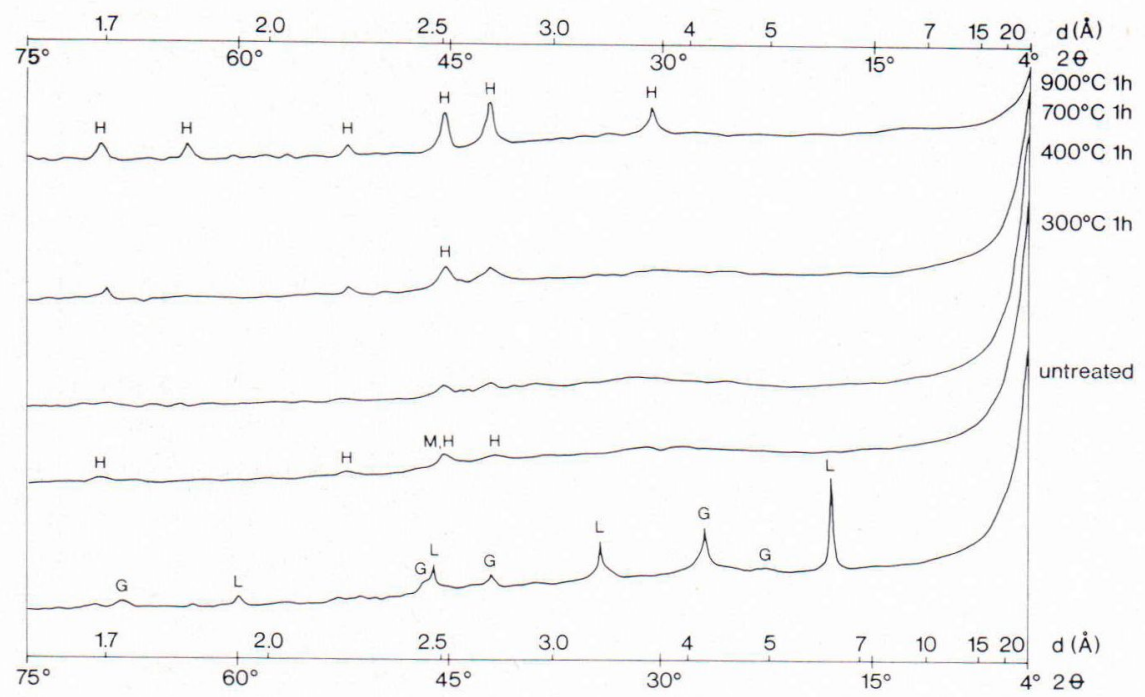

Fig. $9 \mathrm{~b}$. X-ray data of unheated and heated ferruginous precipitate. (Table 2, No. $3 \mathrm{~b}$ ). Symbols as in Fig. 7. The graphs are explained in text.

compositions in Table 2 (Nos. 1, 2, 3 a, and 4 a).

The first mineral to appear was cryptomelane at $200^{\circ} \mathrm{C}$. The material at this temperature was probably a mixture containing birnessite. Birnessite is represented by its non-basal reflections of 2.44 and $1.41 \AA$, the intensities of which decrease upon further heating. In all the samples a broad reflection at $2.39-2.44 \AA$ (cryptomelane $121, \mathrm{~d}=2.39 \AA$ ) was left after heating $1 \mathrm{~h}$ at $400^{\circ} \mathrm{C}$. The intensities of reflections of birnessite and cryptomelane were strongest in Nos. 1 and 2 (Table 2) which contain most $\mathrm{Mn}$, indicating that birnessite converts directly to cryptomelane. Cryptomelane decomposed at temperatures between 300 and $500^{\circ} \mathrm{C}$ and more easily when the content of foreign ions was low.

In sample 3 a (Fig. 9 a) a reflection at $4.00 \AA$ was present between $300^{\circ} \mathrm{C}$ and $530^{\circ} \mathrm{C}$, and the $2.44 \AA$ reflection of birnessite had moved to $2.42 \AA$. If caused by a man- ganese mineral, that mineral may have been nsutite $\left(\gamma-\mathrm{MnO}_{2}, \mathrm{Mn}_{(1-\mathrm{x})}{ }^{4+} \mathrm{Mn}_{\mathrm{x}}{ }^{2+} \mathrm{O}_{(2-2 \mathrm{x})}\right.$ $(\mathrm{OH})_{2 \mathrm{x}}$; McKenzie 1972).

At temperatures above $500^{\circ} \mathrm{C}$ two minerals crystallized: bixbyite, $(\mathrm{Fe}, \mathrm{Mn})_{2} \mathrm{O}_{3}$ (Table 8), whose composition varies from nearly pure $\begin{array}{lllll}\mathrm{Mn}_{2} \mathrm{O}_{3} & \text { to } & 59 & \% & \mathrm{Fe}_{2} \mathrm{O}_{3}\end{array}$ (cubic with $a_{0}=$ $9.365 \AA$ ) and hausmannite (Table 9), $\mathrm{Mn}_{3} \mathrm{O}_{4}$ (Fe: $\mathrm{Mn}=1: 23$, teragonal with $a_{0}=5.75 \AA$ and $c_{0}=9.42 \AA$ ) (Faulring et al. 1960), which appeared with weak reflections at $560^{\circ} \mathrm{C}$ and was present until $1050^{\circ} \mathrm{C}$. In sample No. 1 (Fig. 7) which contained least $\mathrm{Fe}$ (Fe: $\mathrm{Mn}=$ 1:11) hausmannite was the only manganese mineral present. The intensity of reflections increased as the temperature rose, indicating an ordering of structure and growing crystal size. This is in accordance with the observations of Brown et al. (1971) for birnessite containing less than $0.02 \% \mathrm{Fe}$, which recrystallized as hausmannite when heated for $2 \mathrm{~h}$ at $600^{\circ} \mathrm{C}$. In all the samples containing more Fe (Fe: $\mathrm{Mn}$ in sample No. 2, Fig. 8, is 1:6.4; 


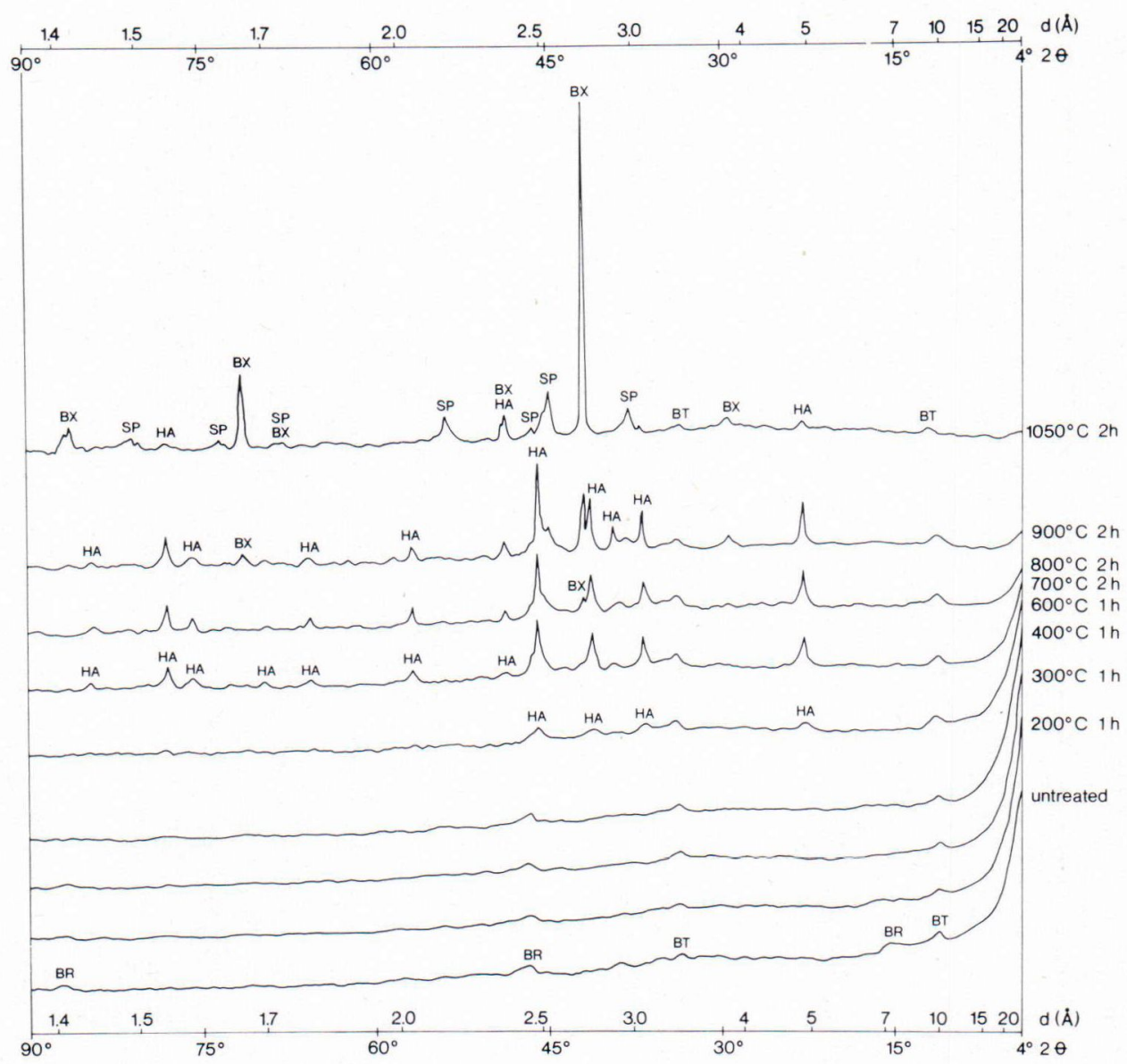

Fig. 10 a. X-ray data of unheated and heated manganiferous precipitate (Table 2, No. 4 a). Symbols as in Fig. 7. The graphs are explained in text.

in No. 3 a, Fig. 9 a, 1: 2.4; and in No. 4 a, Fig. 10, 1:1.3) the dominating mineral above $500^{\circ} \mathrm{C}$ was bixbyite, but hausmannite occurred as well. In sample No. 2 both minerals began to crystallize at $560^{\circ} \mathrm{C}$; in sample No. 3 a bixbyite appeared at $550^{\circ} \mathrm{C}$ and hausmannite at $700^{\circ} \mathrm{C}$; in sample No. 4 a crystallization began with hausmannite at $600^{\circ} \mathrm{C}$ and bixbyite appeared at $800^{\circ} \mathrm{C}$. The intensity of hausmannite reflections began to decrease at higher temperatures: in sample No. 2 above $800^{\circ} \mathrm{C}$, in sample No. 3 a above $1000^{\circ} \mathrm{C}$, and in sample No. 4 a above $900^{\circ} \mathrm{C}$.
At the same time the reflections of bixbyite increased considerably in intensity. Bixbyite appeared first and converted to hausmannite at higher temperatures in the studies of Klingsberg and Roy (1959), McMurdie and Golovato (1948), and Faulring et al. (1960). The material examined by Faulring et al. (1960, Table 1) contained $1.86 \% \mathrm{Fe}_{2} \mathrm{O}_{3}$. The reverse order of crystallization observed for Nos. 2, 3 a, and 4 a in this study is due to the high $\mathrm{Fe}$ content in the samples. The amount of $\mathrm{Fe}$ hausmannite cell is able to hold is dependent of temperature and negligible 


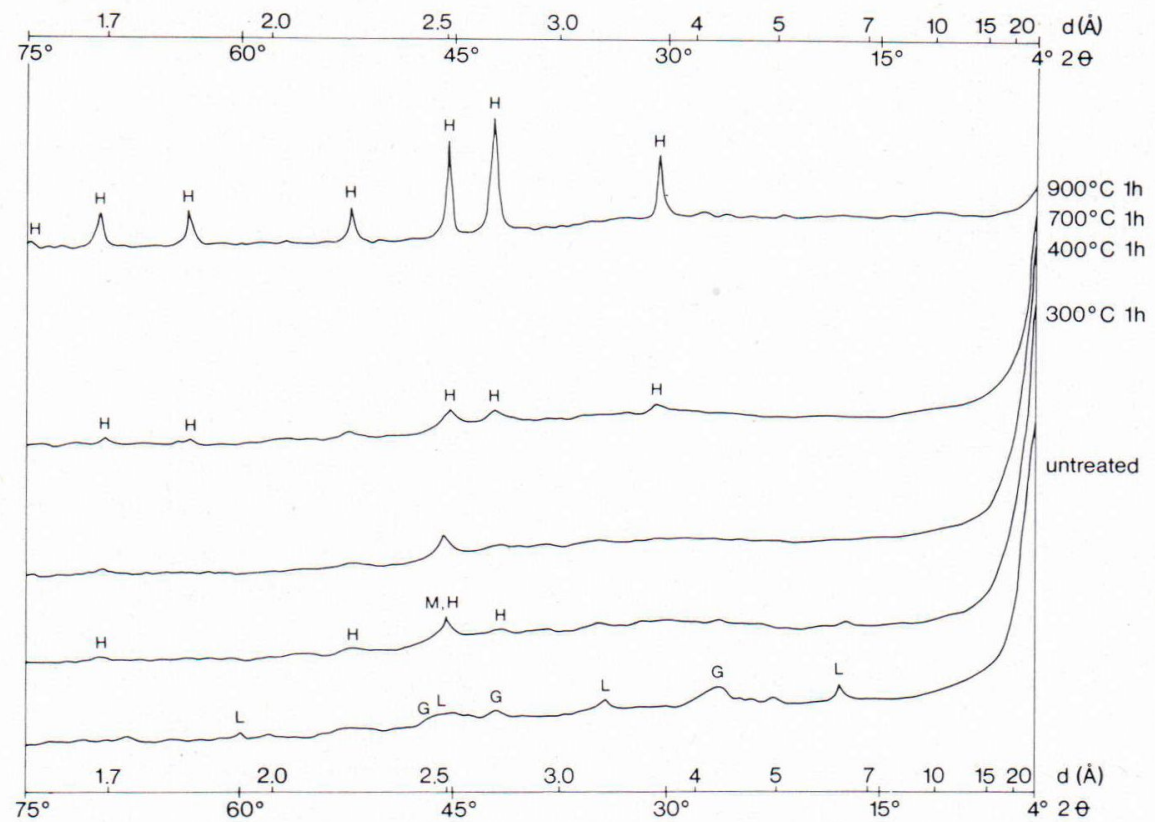

Fig. 10 b. X-ray data of unheated and heated ferruginous precipitate (Table 2, No. 4 b). Symbols as in Fig. 7. The graphs are explained in text.

compared with the amount bixbyite is able to hold.

The last mineral to appear on heating was an oxide with spinel structure. Faulring et al. (1960) report a spinel with $a_{0}=8.42 \AA$ which crystallized after cryptomelane was heated for $17 \mathrm{~h}$ at $900^{\circ} \mathrm{C}$. The spinel crystallized in most samples of this study at $1050^{\circ} \mathrm{C}$, but sample No. 2 displayed broad reflections at $900^{\circ} \mathrm{C}$, indicating small crystallite size. Spinel had a varying chemical composition and different dimensions for the unit cell depending on the total composition of the sample. The $a_{0}$ of sample No. 2 was $8.43 \AA$.

The color of powdered, untreated samples varied from greyish-black to black, excluding sample No. 2 which was brownish-black. Upon heating they first darkened and were dark black at $500-600^{\circ} \mathrm{C}$. Above that temperature they got lighter, becoming greyish- brown. The lightest sample was No. 1 (pure hausmannite) and the darkest No. 3 a (bixbyite dominating), displaying the colors of hausmannite and bixbyite, respectively. With the crystallizing of spinel the samples became darker again. The shade after $2 \mathrm{~h}$ at $1050^{\circ} \mathrm{C}$ was brownish-black to brown, and in sample No. 1 dark red-brown.

Recrystallization of ferruginous precipitates upon heating

According to Rooksby (1972), goethite begins to decompose in air at c. $250^{\circ} \mathrm{C}$ and is completely recrystallized as $\alpha-\mathrm{Fe}_{2} \mathrm{O}_{3}$ (hematite) when heated $1 \mathrm{~h}$ at $300^{\circ} \mathrm{C}$ in a slow current of air. The change from goethite to hematite is pseudomorphic in character and the transformation thus takes place without entire disruption of the original atomic packing. The crystallite size at $300^{\circ} \mathrm{C}$ remains so 
small as to give broadened reflections in $\mathrm{X}-$ ray patterns. The broadening is not uniform; reflections associated with planes of atoms suffering least disorganization on transformation are relatively sharp (e.g. 110, 113,116 , and 300 ) while the others are considerably broadened. The crystal size increases rapidly as the ignition temperature is raised, and at $700^{\circ} \mathrm{C}$ no measurable broadening of reflections remains. Crystal size is then c. $0.5 \mu \mathrm{m}$ and the color Turkey red. At higher temperatures, $900^{\circ} \mathrm{C}$ and above, the crystal size increases several micrometers and the color becomes darker.

When lepidocrocite is heated, $\gamma-\mathrm{Fe}_{2} \mathrm{O}_{3}$ (Rooksby 1972), maghemite (Bernal et al. 1957), is the first mineral to form. Lepidocrocite decomposes completely when it is heated $1 \mathrm{~h}$ at $300^{\circ} \mathrm{C}$; the crystallites formed are extremely small and X-ray reflections appreciably broadened. Transformation to $a$-structure occurs totally at c. $400^{\circ} \mathrm{C}$ (Bernal et al. 1957). Transformation of lepidocrocite to maghemite is pseudomorphic. The small crystallite size and consequent broadening of reflections as well as lack of ordering of lattice vacancies hinder the detection of most of the reflections (Rooksby 1972).

The changes in X-ray patterns of ferruginous samples as a result of heat treatment are shown in Figs. $9 \mathrm{~b}$ and $10 \mathrm{~b}$. The first reflection to appear, at $300^{\circ} \mathrm{C}$, was that at $2.51 \AA$ (110 of hematite, 313 of maghemite). No other reflections of maghemite could be detected, but three further faint reflections of hematite were detected at 300 and $400{ }^{\circ} \mathrm{C}$ : $2.69 \AA$ (104), $2.20 \AA$ (113), and $1.69 \AA$ (116). At $700^{\circ} \mathrm{C}$ the intensity of the reflection of hematite at $2.51 \AA$ was still stronger than that at $2.69 \AA$, because the 110 -plane $(2.51 \AA)$ suffers less dis-organization on transformation from goethite structure than the 104plane $(2.69 \AA)$ does, and the structure of hematite is still disordered. The samples heated for $1 \mathrm{~h}$ at $900^{\circ} \mathrm{C}$ showed perfect X-ray patterns of hematite (Table 10).

At $300^{\circ} \mathrm{C}$, the powdered samples turned from their original yellowish color to reddishbrown. The shade deepened as the temperature was raised, so that at $900^{\circ} \mathrm{C}$ the color was darker than at $700^{\circ} \mathrm{C}$.

\section{Conclusions}

When the suitable $\mathrm{pH}-\mathrm{Eh}$ conditions prevail manganese is precipitated with iron from groundwater in sorted sediments. On average, manganese compounds are more soluble than iron compounds, but precipitates rich in manganese are found even in areas where iron predominates in groundwater. In sand and gravel, manganese is apparently removed from solution before iron, even through it needs higher $\mathrm{pH}-\mathrm{Eh}$ conditions to precipitate. This phenomenon can be attributed to the greater stability of Fe- than Mn-complexes, usually organic, formed in soils (cf. Vasari et al. 1972). For complex compounds the oxidation and precipitation of iron is much slower than that of manganese; most of it stays in dissolved form when groundwater reaches aerated sites in esker, and precipitates rich in manganese are formed. In the case investigated here the $\mathrm{Fe} / \mathrm{Mn}$-ratios in bedrock, groundwater, and manganiferous precipitate were 100,25 , and 0.1 , respectively.

In homogeneous sediments, Mn-rich precipitates overlie Fe-rich ones. Possibly this phenomenon could be used as an indicator of sedimentation conditions and of the upper sides of sediments (e.g., in overturned strata in metasediments). Mn-precipitates tend to dissolve once they become buried, however.

In moist sediments, $\mathrm{Mn}$ - and under stronger reducing conditions, also $\mathrm{Fe}$ - may be partly dissolved and migrate to areas in sediments where oxidizing conditions prevail, for example, to stony clusters in sand, which are aerated especially during dry seasons. 
Upon dissolving, oxidates become purer through the release of coprecipitated cations, and iron and manganese, through crystallization and partial reduction and oxidation, may separate from each other during deposition and the early burial stage.

The precipitates studied were composed of hydrous iron and manganese oxides, and the minerals observed were birnessite in manganiferous, and goethite and lepidocrocite in ferruginous precipitates. Iron and manganese minerals were not found in the same precipitate even when large amounts of iron were found in manganiferous precipitates. This indicates that in the early stage of crystallization birnessite may incorporate considerable amounts of foreign elements.

The recrystallization and probably even the behavior of oxidate cements during diagenesis and metamorphosis under oxidizing conditions can be studied by heating them in air. Upon ignition, birnessite recrystallizes as spinel and hausmannite if iron-poor and as spinel and bixbyite if iron-rich. Iron precipitates recrystallize as hematite.

Acknowledgements - Financial support from The Foundation for the Investigation of Natural Resources in Finland is gratefully acknowledged. The chemical water analyses were made in the Department of Quaternary Geology of the Geological Survey of Finland under the leadership of Juho Hyyppä, Phil. Lic. Figures $1-3$ were drawn by Misses Päivi Määttänen and Hilkka Haavisto and $7 \multimap 10$ by Mrs. Hilkka Falkseth. Mr. Markku Putkinen assisted in field investigations. To all these persons the authors wish to offer their thanks for the valuable assistance received.

\section{REFERENCES}

Aaltonen, V. T. (1941) Zur Stratigraphie des Podsolprofils besonders vom Standpunkt der Bodenfruchtbarkeit. Comm. Inst. Forest. Fenniae 29: $1-47$.

Alhonen, P., Koljonen, T., Lahermo, P., and Uusinoka, R. (1975) Ferruginous concretions around root channels in clay and fine sand deposits. Bull. Geol. Soc. Finland 47: 175-181.

Barnes, S. (1967) Minor element composition of ferromanganese nodules. Science 157: 63-65.

Bernal, J. D., Dasgupta, D. R., and Mackay, A. L. (1957) Oriented transformations in iron oxides and hydroxides. Nature 180: 645-647.

- (1959) The oxides and hydroxides of iron and their structural inter-relationships. Clay Miner. 4: $15-30$.

Birnbaum, H., Cohen, H., and Sidhu, S. S. (1947) X-ray diffraction studies on color variation of iron oxide pigments. J. Appl. Phys. 18: 27 -29 .

Bricker, O. (1965) Some stability relations in the system $\mathrm{Mn}-\mathrm{O}_{2}-\mathrm{H}_{2} \mathrm{O}$ at $25^{\circ}$ and one atmosphere total pressure. Am. Miner. 50: 1296-1354.

Brown, F. H., Pabst, A., and Sawyer, D. L. (1971) Birnessite on colemanite at Boron, California. Am. Miner. 56: 1057-1064.
Bunn, C. W. (1941) Some applications of X-ray diffraction methods in industrial chemistry. J. Sci. Instrum. 18: $70-74$.

Buser, W., Graf, P., and Feitknecht, W. (1954) Beitrag zur Kenntnis der Mangan(II)-manganite und des $\delta-\mathrm{MnO}_{2}$. Helv. Chim. Acta 37: $2322-2333$.

Buser, W. and Grütter, A. (1956) Über die Natur der Manganknollen. Schweiz. Miner. Petrogr. Mitt. 36: $49-62$.

Cronan, D. S. and Tooms, J. S. (1969) The geochemistry of manganese nodules and associated pelagic deposits from the Pacific and Indian Oceans. Deep-Sea Res. 16: 335-359.

Faulring, G. M., Zwicker, W. K., and Forgeng W. D. (1960) Thermal transformation and properties of cryptomelane. Am. Miner. 45: $946-959$.

Feitknecht, W. and Marti, W. (1945) Über die Oxydation von Mangan(II)-hydroxyd mit molekularem Sauerstoff. Helv. Chim. Acta 28: 129 -148 .

Finkelman, R. B., Evans, H. T., and Matzko, J. J. (1974) Manganese minerals in geodes from Chihuahua, Mexico. Miner. Mag. 39: 549-558. 
Finkelman, R. B., Matzko, J. J., Woo, C. C., White, J. S., Jr., and Brown, W. R. (1972) A scanning electron microscopy study of minerals in geodes from Chihuahua, Mexico. Miner. Record 3: $205-212$.

Frondel, C., Marvin, U. B., and Ito, J. (1960) New data on birnessite and hollandite. Am. Miner. 45: $871-875$.

Giovanoli, R., Stähli, E., and Feitknecht, W. (1970) Über Oxihydroxide des vierwertigen Mangans mit Schichtengitter. 1. Natriummangan (II, III) manganat (IV). Helv. Chim. Acta 53: 209-220.

Glasby, G. P. (1972) The mineralogy of manganese nodules from a range of marine environments. Mar. Geol. 13: 57-72.

Glemser, O., Gattow, G., and Meisiek, H. (1961) Über Manganoxyde. VII. Darstellung und Eigenschaften von Braunsteinen. I. (Die $\delta-$ Gruppe der Braunsteine). Z. Anorg. Allg. Chem. 309: 1-19.

Halbach, P. (1975) Mineralogical and geochemical investigations on Finnish lake ores. Bull. Geol. Soc. Finland 48: $33-42$.

Hariya, Y. (1961) Mineralogical studies on manganese dioxide and hydroxide minerals in Hokkaido, Japan. J. Fac. Sci. Hokkaido Univ., Ser. IV, Geol. Miner. 10: 641-702.

Hem, J. D. (1963) Chemical equilibria and rates of manganese oxidation. U.S. Geol. Surv., Water-Supply Pap. 1667-A.

- (1964) Deposition and solution of manganese oxides. U.S. Geol. Surv., Water-Supply Pap. 1667-B.

Jauhiainen, E. (1969) On soils in the boreal coniferous region. Fennia 98. $123 \mathrm{p}$.

- (1973 a) Effect of climate on podzolization in southwest and eastern Finland. Soc. Sci. Fenn., Commentat. Phys.-Math. 43: 213-242.

- $(1973 \mathrm{~b})$ Age and degree of podzolization of sand soils on the coastal plain of northwest Finland. Soc. Sci. Fenn., Commentat. Biol. 68. $32 \mathrm{p}$.

JCPDS, Joint Committee on Powder Diffraction Standards (1974) Selected powder diffraction data for minerals, ed. L. G. Berry, Philadelphia.

Jones, L. H. P. and Milne, A. A. (1956) Birnessite, a new manganese oxide mineral from Aberdeenshire, Scotland. Miner. Mag. 31: 283-288.

Klingsberg, C. and Roy, R. (1959) Stability and interconvertibility of phases in the system Mn-O-OH. Am. Miner. 44: 819-838.
Koljonen, T. and Carlson, L. (1975) Behaviour of the major elements and minerals in sediments of four humic lakes in southwestern Finland. Fennia 137. 47 p.

Krauskopf, K. B. (1957) Separation of manganese from iron in sedimentary processes. Geochim. Cosmochim. Acta 12: 61-84.

Larson, L. T. (1962) Zinc bearing todorokite from Philipsburg, Montana. Am. Miner. 47: 59-66.

Lehijärvi, M. (1970) [Map of Pre-Quaternary rocks], 3112 Heinola. Geological Map of Finland, $1: 100000$.

Levinson, A. A. (1962) Birnessite from Mexico. Am. Miner. 47: 790-791.

McKenzie, R. M. (1971) The synthesis of birnessite, cryptomelane and some other oxides and hydroxides of manganese. Miner. Mag. 38: 493-502.

- (1972) The manganese oxides in soils - A review. Z. Pflanzenernaehr. Bodenkd. 131: 221 -242 .

McMurdie, H. F. (1944) Microscopic and diffraction studies on dry cells and their raw materials. Trans. Electrochem. Soc. 86: 313-326.

McMurdie, H. F. and Golovato, E. (1948) Study of modifications of manganese dioxide. J. Res. Nat. Bur. Stand. 41: 589-600.

Norrish, K. and Taylor, R. M. (1961) The isomorphous replacement of iron by aluminium in soil goethites. J. Soil Sci. 12: 294-306.

Ostwald, J. (1975) Mineralogy of manganese oxides from Groote Eylandt. Miner. Deposita 10: $1-12$.

Rooksby, H. P. (1972) Oxides and hydroxides of aluminium and iron. The X-ray Identification and Crystal Structures of Clay Minerals, ed. by G. Brown, 354-392. Mineralogical Society, London.

Shepps, V. C. and Fairbridge, R. W. (1968) Esker. The Encyclopedia of Geomorphology, ed. by R. W. Fairbridge, 323-325. Reinhold Book Corporation, New York, Amsterdam, and London. $1295 \mathrm{p}$.

Sorem, R. K. and Gunn, D. W. (1967) Mineralogy of manganese deposit Olympic Peninsula, Washington. Econ. Geol. 62: 22-56.

Taylor, R. M. (1968) The association of manganese and cobalt in soils - further observations. J. Soil Sci. 19: $77-80$.

Taylor, R. M. and McKenzie, R. M. (1966) The association of trace elements with manganese minerals in Australian soils. Austr. J. Soil Res. 4: $29-39$. 
Taylor, R. M., McKenzie, R. M., and Norrish, K. Vasari, Y., Koljonen, T., and Laakso, K. (1972) (1964) The mineralogy and chemistry of manganese in some Australian soils. Austr. J. Soil Res. 2: 235-248. A case of manganese precipitate in the Taviharju esker, Kuusamo, North East Finland. Bull. Geol. Soc. Finland 44: 133-140.

Manuscript received, March 10, 1976. 